The copyright $\odot$ of this thesis belongs to its rightful author and/or other copyright owner. Copies can be accessed and downloaded for non-commercial or learning purposes without any charge and permission. The thesis cannot be reproduced or quoted as a whole without the permission from its rightful owner. No alteration or changes in format is allowed without permission from its rightful owner. 
THE DETERMINANTS OF TURNOVER INTENTION AMONG BANK EMPLOYEES

YEO CHIU HOON

MASTER OF HUMAN RESOURCE MANAGEMENT UNIVERSITI UTARA MALAYSIA

MARCH 2018 


\section{THE DETERMINANTS OF TURNOVER INTENTION \\ AMONG BANK EMPLOYEES}

By

\section{YEO CHIU HOON}
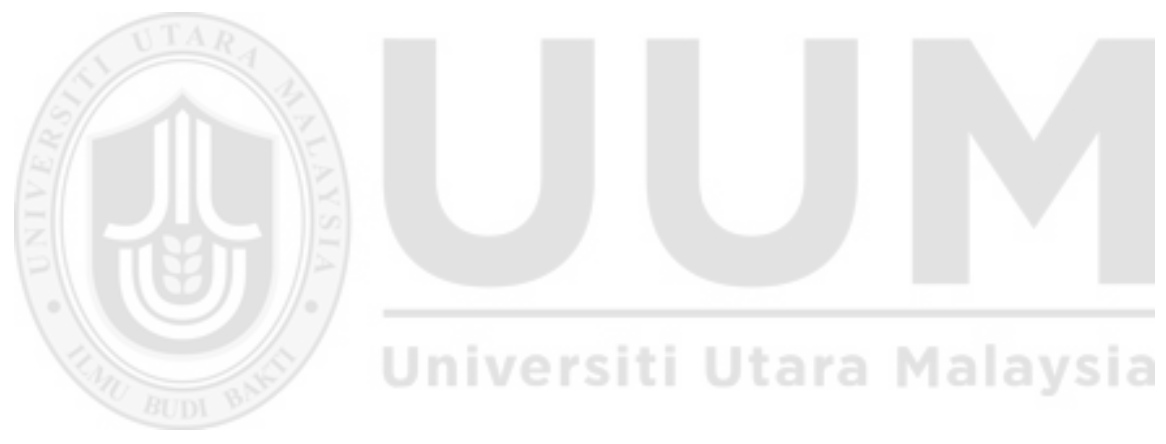

Thesis Submitted to the

Othman Yeop Abdullah Graduate School of Business

Universiti Utara Malaysia

in Fulfillment of the Requirement for the Degree of Master of Human Resource Management 


\section{PERAKUAN KERJA KERTAS PENYELIDIKAN \\ (Certification of Research Paper)}

Saya, mengaku bertandatangan, memperakukan bahawa

(1, the undersigned, certified that)

\section{YEO CHIU HOON (820238)}

Calon untuk ljazah Sarjana

(Candidate for the degree of)

MASTER OF HUMAN RESOURCE MANAGEMENT

telah mengemukakan kertas penyelidikan yang bertajuk

(has presented his/her research paper of the following title)

\section{THE DETERMINANTS OF TURNOVER INTENTION AMONG BANK EMPLOYEES}

Seperti yang tercatat di muka surat tajuk dan kulit kertas penyelidikan (as it appears on the title page and front cover of the research paper)

Bahawa kertas penyelidikan tersebut boleh diterima dari segi bentuk serta kandungan dan meliputi bidang ilmu dengan memuaskan.

(that the research paper acceptable in the form and content and that a satisfactory knowledge of the field is covered by the research paper).
Nama Penyelia Pertama
DR. HADZIROH BT. IBRAHIM
(Name of f Supervisor)
Tandatangan
(Signature)

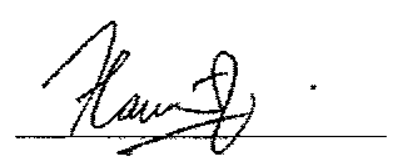
Nama Penyelia Kedua
DR. TANG SWEE MEI
(Name of $2^{\text {nd }}$ Supervisor)
Tandatangan

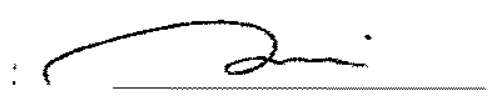
(Signature)
Tarikh
(Date) 


\section{PERMISSION TO USE}

In presenting of this dissertation or research paper in partial fulfillment of the requirements for a postgraduate degree from Universiti Utara Malaysia (UUM), I agree that the University Utara Malaysia (UUM) may make a freely available for inspection. I further agree that permission for copying of this dissertation or research paper in any manner, in whole or in part, for scholarly purpose may be granted by my supervisor(s) or, in their absence by the Dean of Othman Yeop Abdullah Graduate School of Business. It is understood that any copying or publication or use of this dissertation or research paper or parts thereof for financial gain shall not be given to me and Universiti Utara Malaysia (UUM) for any scholarly use which may be made of any material from my dissertation or research paper.

Requested for permission to copy or make other use of materials in this dissertation or research paper, in whole or in part should be addressed to:

Dean of Othman Yeop Abdullah Graduate School of Business

Universiti Utara Malaysia (UUM)

06010 UUM Sintok

Kedah Darul Aman 


\begin{abstract}
The main purpose of this research is to investigate the determinants of turnover intention among bank employees in Kuala Lumpur. Specifically, the objective of this study is to examine the relationships between employee relations, working environment and conditions, compensation and benefit packages, career advancement opportunities with turnover intention. A total of 150 questionnaires were distributed among bank employees in Masjid Jamek area and the researcher was successfully collected 120 questionnaires from the respective respondents. All the data were analyzed by using Statistical Package for Social Science (SPSS) 23.0 versions. Two types of data analysis were used, which are descriptive analysis and inferential analysis. Descriptive analysis is used to study the respondent demographic information's such as age, gender, highest education level, length of services, and monthly income level, meanwhile, the inferential analysis is used to determine the relationships between independent variables such as employee relations, working environment and conditions, compensation and benefit packages, career advancement opportunities and dependent variable which is turnover intention. The results of the study show that the relationship between turnover intention and employee relations is weak. However, working environment and conditions, compensation and benefit packages, and career advancement opportunities are moderately correlated to the turnover intention among the bank employees in Masjid Jamek area, Kuala Lumpur, Malaysia. Based on the multiple regression analysis, the study found that two independent variables which are working environment and conditions, and compensation and benefit packages have negative and significant relationship with turnover intention.
\end{abstract}

Keywords: Turnover Intention, Employee Relations, Working Environment and Conditions, Compensation and Benefit Packages, Career Advancement Opportunities 


\begin{abstract}
ABSTRAK
Tujuan utama kajian ini adalah untuk meneliti faktor-faktor penentu bagi hasrat untuk berhenti dalam kalangan pekerja institusi perbankan, Kuala Lumpur. Secara khususnya, objektif kajian ini adalah untuk mengenalpasti hubungan antara hubungan pekerja, persekitaran dan keadaan bekerja, pakej ganjaran dan faedah, peluang peningkatan kerjaya dan hasrat untuk berhenti. Sejumlah 150 soal selidik telah diedarkan kepada pekerja bank di kawasan Masjid Jamek, Kuala Lumpur dan penyelidik berjaya memperolehi 120 soal selidik daripada responden. Semua data telah dianalisis dengan menggunakan Statistical Package for Social Science (SPSS) versi 23.0. Dua jenis analisis data telah digunakan iaitu analisis deskriptif dan analisis inferensi. Analisis deskriptif digunakan untuk mengkaji maklumat demografi responden dari segi umur, jantina, tahap pendidikan tertinggi, tempoh perkhidmatan, dan tahap pendapatan bulanan, manakala, analisis inferensi digunakan untuk mengenalpasti hubungan antara pembolehubah bebas seperti hubungan pekerja, persekitaran dan keadaan bekerja, pakej ganjaran dan faedah, peluang peningkatan kerjaya, dan pembolehubah bersandar iaitu hasrat untuk berhenti. Hasil kajian menunjukkan hubungan yang lemah antara hasrat untuk berhenti dan hubungan pekerja. Walaubagaimanapun, persekitaran dan keadaan bekerja, pakej pampasan dan faedah, dan peluang peningkatan kerjaya mempunyai hubungan yang sederhana dengan hasrat untuk berhenti dalam kalangan pekerja di institusi perbankan di kawasan Masjid Jamek, Kuala Lumpur. Berdasarkan analisis regresi berganda, kajian mendapati bahawa hanya dua faktor iaitu persekitaran dan keadaan bekerja, dan pakej pampasan and faedah mempunyai hubungan yang negatif dan signikasi dengan faktor hasrat untuk berhenti.
\end{abstract}

Keywords: Hasrat untuk berhenti, Hubungan pekerja, Persekitaran dan keadaan bekerja, Pakej ganjaran dan faedah, Peluang peningkatan kerjaya. 


\section{ACKNOWLEDGEMENT}

First and foremost, I would like to convey my grateful thanks to Universiti Utara Malaysia (UUM) for giving me the opportunity to further my Master studies and to conduct my research paper in partial fulfillment of the requirements for a postgraduate degree.

Moreover, I would like to thank to my research supervisors, Dr. Hadziroh Binti Ibrahim and Dr. Tang Swee Mei for the valuable guidance and advice from the beginning of my research paper towards the end. They are inspired me greatly to work in this research paper. Furthermore, their willingness to motivate me has contributed tremendously to my research paper.

In addition, I would also like to express my truly appreciation to all respondents from the banking industry in Masjid Jamek area, Kuala Lumpur for their time, cooperation and contributions in this research paper. I am deeply grateful for their willingness to share information by completing the questionnaires provided. Not forgotten to my friends, Eunise-Chuah, Lee Pei Shan, Natalie Yap Siew Hwee, and Chin Lee Ying for their willingness to come to Masjid Jamek area, Kuala Lumpur to help me giving out the questionnaires to the target respondents.

Last but not least, I would like to give a special thanks to my family members who has sacrificed a lot for me in terms of time, perspiration and money to ensure my success in life. Other than that, I would also like to thanks for those people and my friends that have helped me directly and indirectly during the completion of the research paper. 


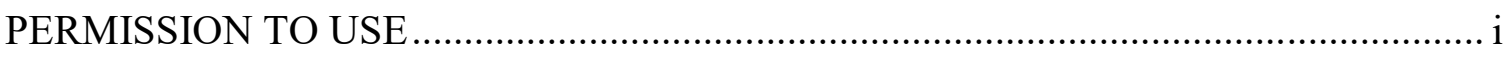

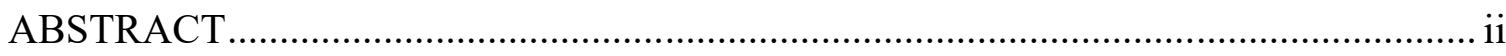

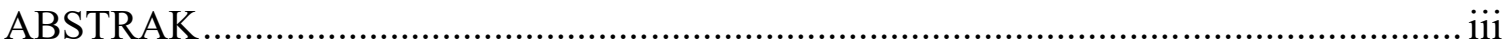

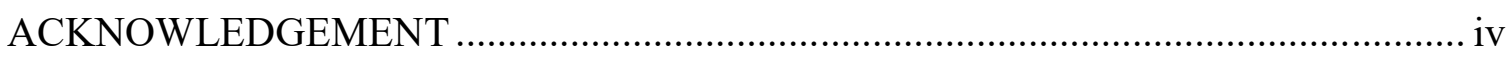

TABLE OF CONTENTS ..................................................................................... v

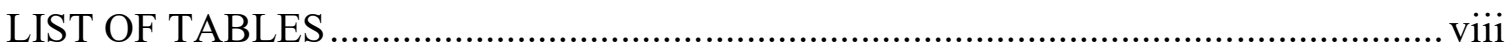

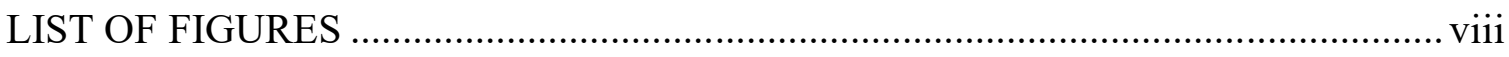

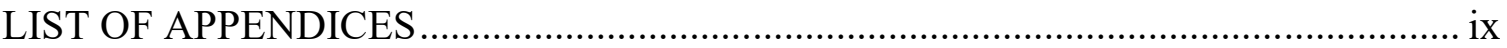

\section{CHAPTER ONE: INTRODUCTION}

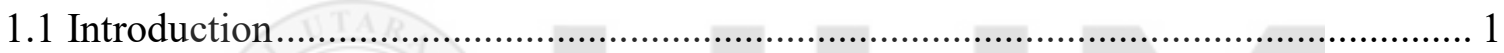

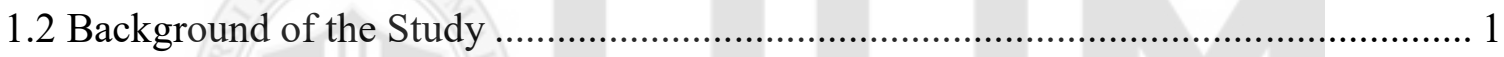

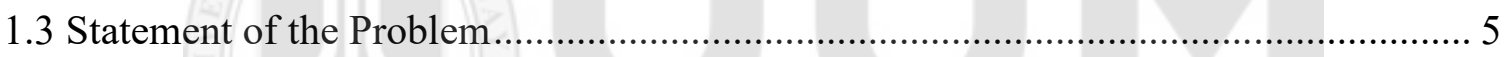

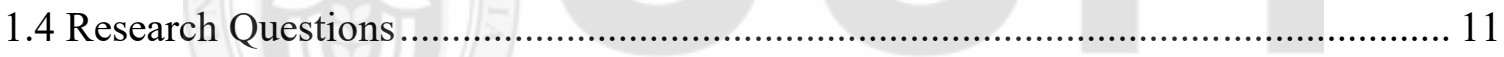

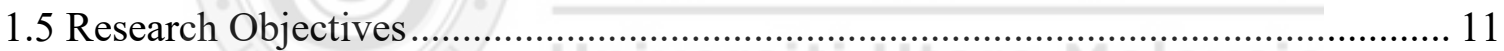

1.6 Significance of the Study .......................................................................... 12

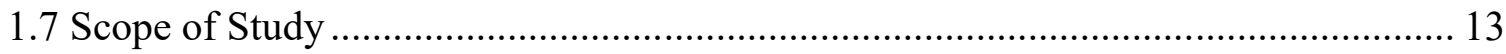

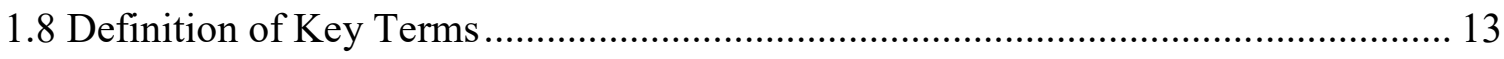

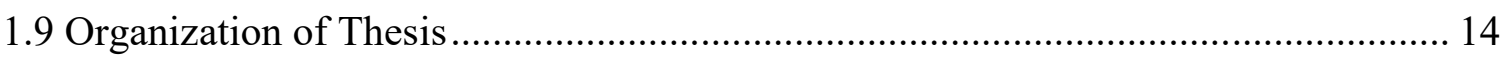

\section{CHAPTER TWO: LITERATURE REVIEW}

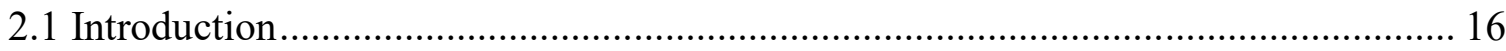

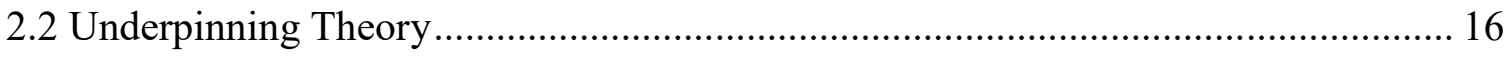

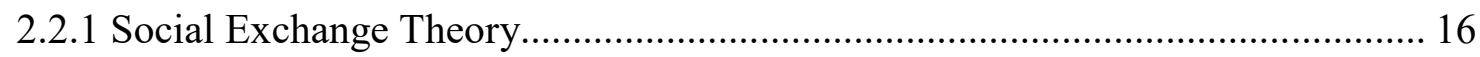

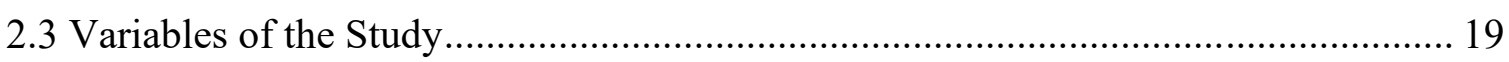

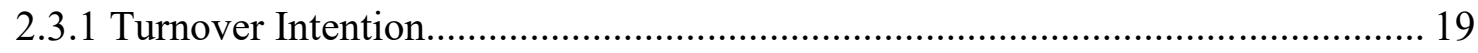

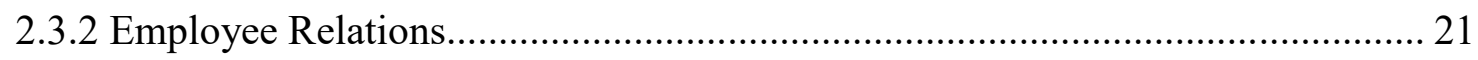

2.3.3 Working Environment and Conditions …………........................................... 24

2.3.4 Compensation and Benefit Packages ............................................................. 26 


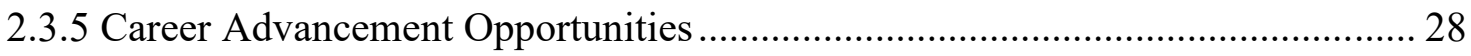

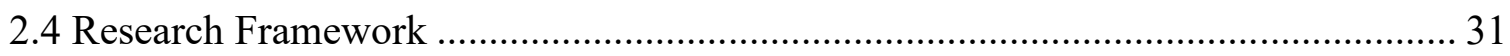

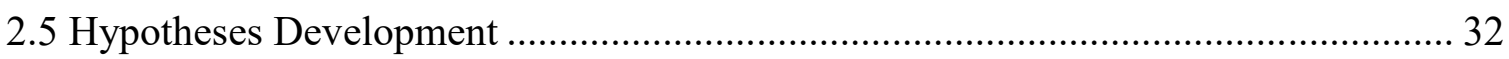

2.5.1 Employee Relations and Turnover Intention ................................................ 32

2.5.2 Working Environment and Conditions and Turnover Intention ......................... 32

2.5.3 Compensation and Benefit Packages and Turnover Intention ............................ 33

2.5.4 Career Advancement Opportunities and Turnover Intention ............................... 34

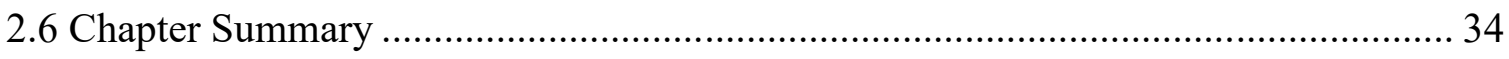

\section{CHAPTER THREE: RESEARCH METHODOLOGY}

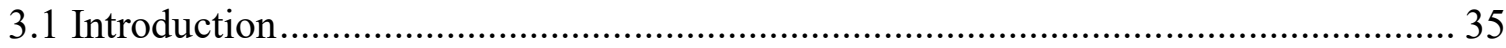

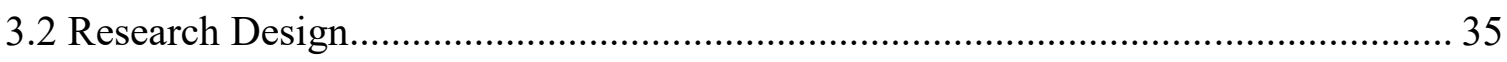

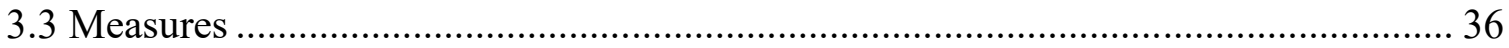

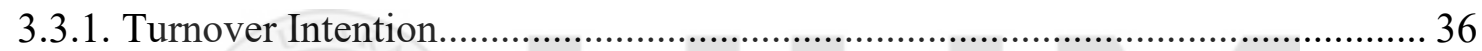

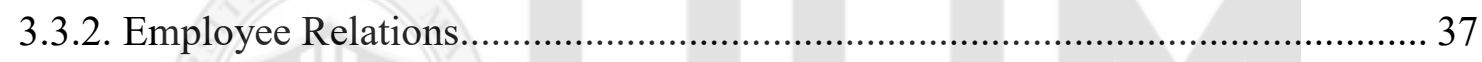

3.3.3. Working Environment and Conditions ........................................................... 38

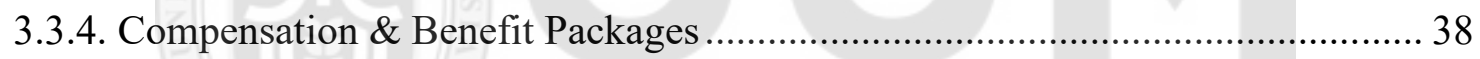

3.3.5. Career Advancement Opportunities ................................................................. 39

3.4 Data Collection Procedures...................................................................... 41

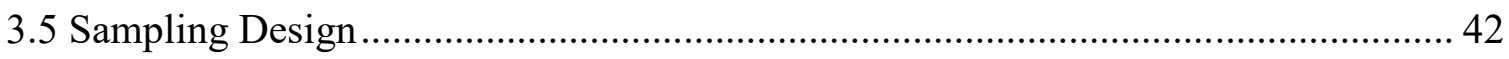

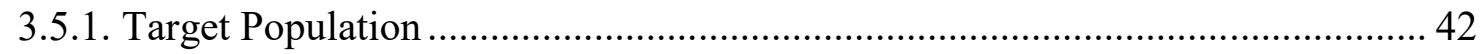

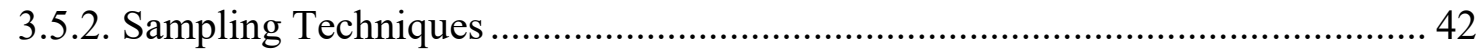

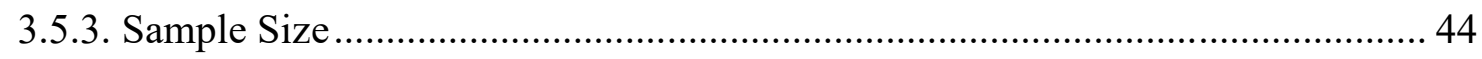

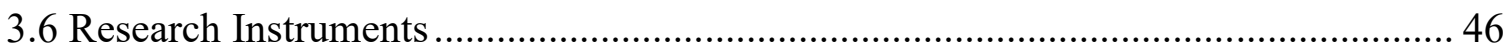

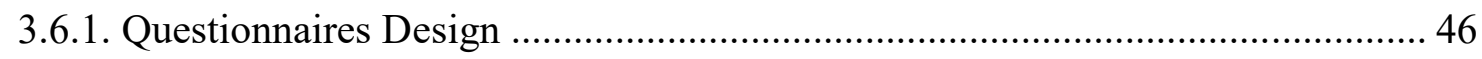

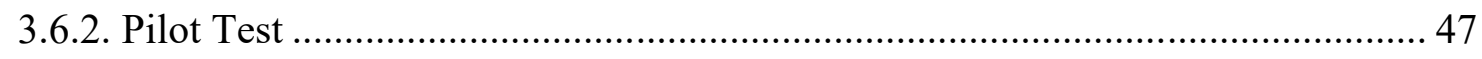

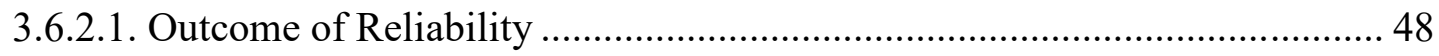

3.7 Data Analysis Techniques........................................................................................ 49

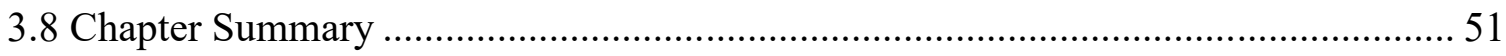




\section{CHAPTER FOUR: RESULTS AND DISCUSSION}

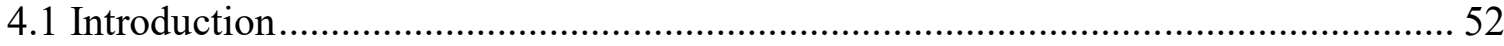

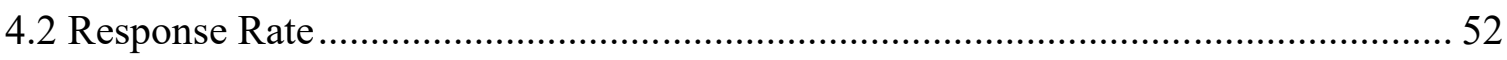

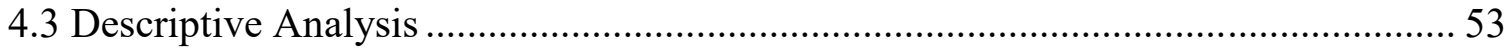

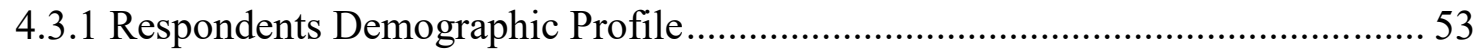

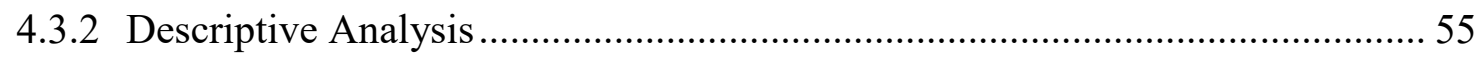

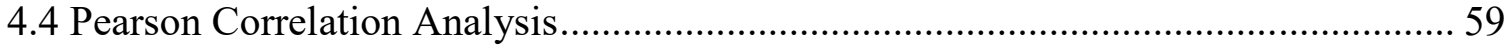

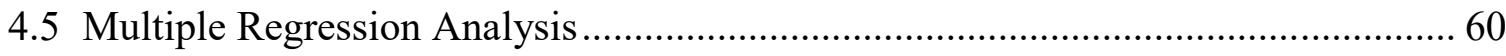

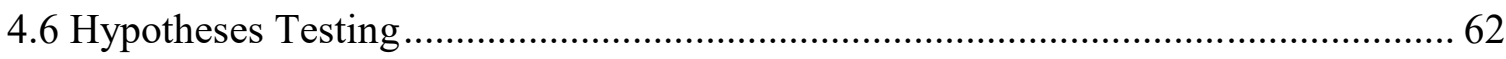

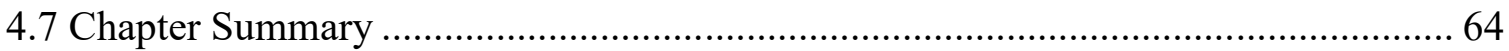

\section{CHAPTER FIVE: DISCUSSION AND CONCLUSION}

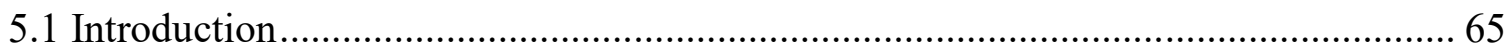

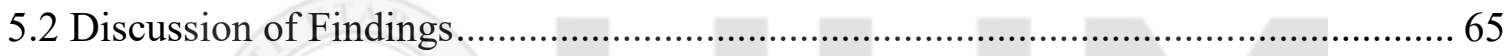

5.2.1 The relationship between employee relations and turnover intention ............... 65

5.2.2 The relationship between working environment and conditions and turnover

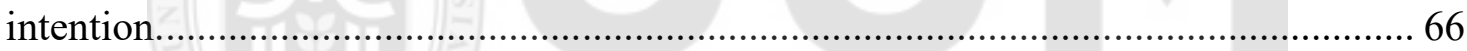

5.2.3 The relationship between compensation and benefit packages and turnover

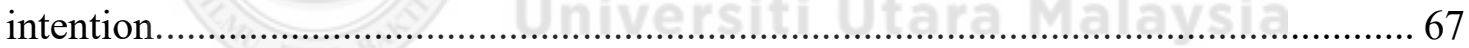

5.2.4 The relationship between career advancement opportunities and turnover

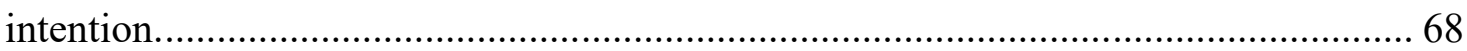

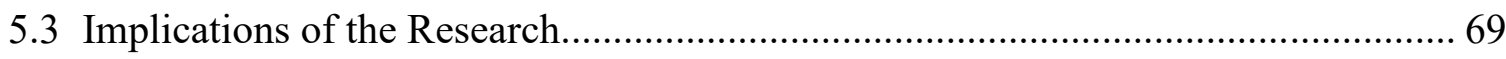

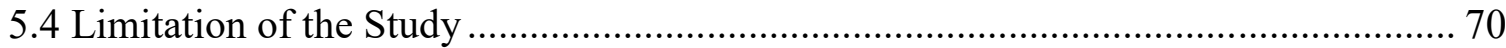

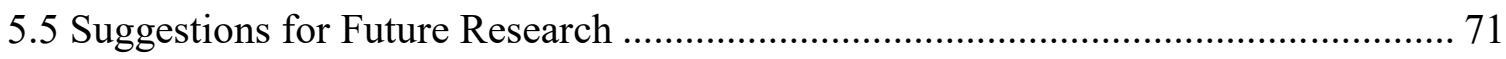

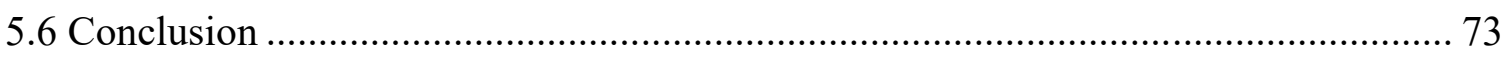

REFERENCES

APPENDICES 


\section{LIST OF TABLES}

Table 1.1 Unemployment Rate in Malaysia from 2010-2016 ……………………….... 2

Table 1.2 Number of Employees being Terminate from Jan-Jun 2016 ……………….... 5

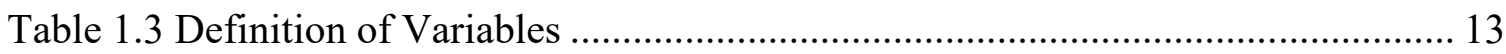

Table 3.1 Items represent the Turnover Intention............................................................ 37

Table 3.2 Items represent the Employee Relations.......................................................... 37

Table 3.3 Items represent the Working Environment and Conditions............................... 38

Table 3.4 Items represent the Compensation and Benefit Packages ................................ 39

Table 3.5 Items represent the Career Advancement Opportunities .................................... 40

Table 3.6 Number of Employees from Respective Banking Institutions ......................... 42

Table 3.7 Table for Determining Sample Size from a Given Population.......................... 45

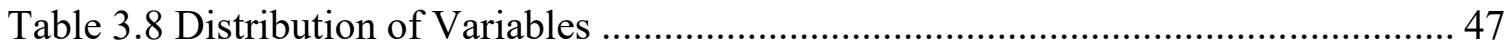

Table 3.9 Cronbach's Alpha Coefficient Result for All the Variables ............................. 48

Table 3.10 Internal Consistency for Cronbach's Alpha Coefficient................................ 48

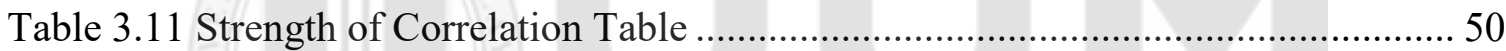

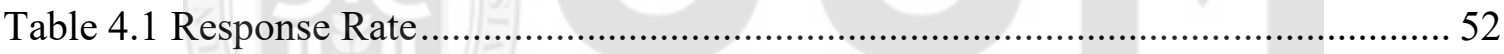

Table 4.2 Respondents Demographic Profile ............................................................. 53

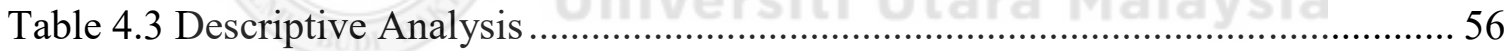

Table 4.4 Pearson's Correlation Analysis Results ....................................................... 59

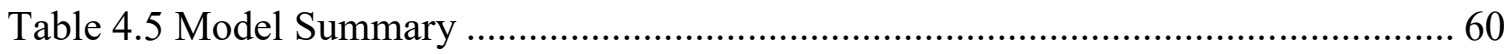

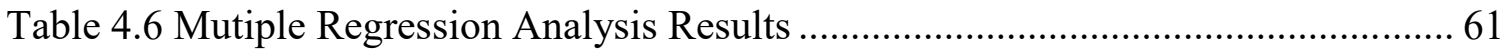

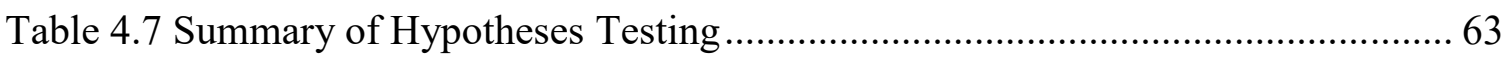

\section{LIST OF FIGURES}

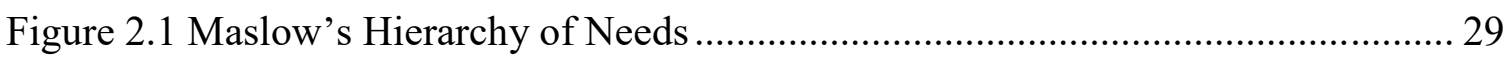

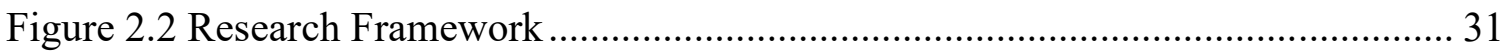




\section{LIST OF APPENDICES}

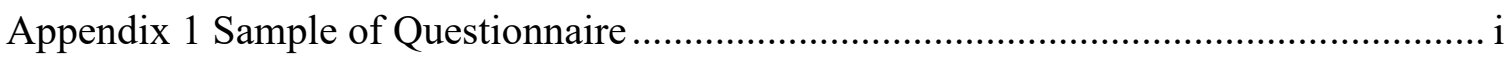

Appendix 2 Pilot Test Results..................................................................................... vi

Appendix 3 Descriptive Analysis Results for Demographic Profile ................................. xi

Appendix 4 Descriptive Analysis Results for All Variables ........................................... xii

Appendix 5 Pearson Correlation Analysis Results .......................................................... xiv

Appendix 6 Multiple Regression Analysis Results ....................................................... Xv 


\section{CHAPTER ONE \\ INTRODUCTION}

\subsection{Introduction}

This chapter presents background of the study, statement of the problem, research questions, research objectives, significance of the study, scope of study, definition of key terms, and organization of thesis.

\subsection{Background of the Study}

Nowadays, most of the organizations are facing employee turnover issue. This issue has been become a trend in job market and they would like to leave their current organizations due to some reasons. A study conducted by Dysvik and Kuvaas (2010) stated that the issue of employee turnover have been recognized as a major managerial concern in all organizations. Huang and $\mathrm{Su}$ (2016) defined the employee turnover intention as the employees' conscious and deliberate willingness to leave the organization. Rahim and Cosby (2016) stated that the employee turnover is referring to the employees leaving an organization voluntarily and not being terminated by the organization.

Based on studies of Shukla and Sinha (2013), they defined employees' turnover is the ratio of the number of organizations members who left and divided by the average number of people in the organizations. The turnover intention of employees is one of the behavioral intentions to quit from the organizations (Rahman \& Iqbal, 2013). As a result of high employees' turnover will cause the organizations losing the knowledge and 
intellectual asset, which are the people. This is because the entire assets are removing out from organizations once the employees are leaving. Therefore, these phenomena will impact the organizations to allocate huge amount of monetary and time in order to gain the intellectual asset of the new employees.

The total employees' turnover has contributed to unemployment rate. Based on Labour Force Statistics Malaysia (2016) and Department of Statistics Malaysia (2016), the unemployment rate fluctuate from year 2011 decreases to $3.0 \%$ in 2012 and it increases to $3.1 \%$ in year 2013 . However, it declines to $2.9 \%$ in 2014 and rose up again to $3.1 \%$ in year 2015 and $3.5 \%$ in year 2016 as shows in Table 1.1.

Table 1.1

Unemployment Rate in Malaysia from 2010-2016

\begin{tabular}{cccccc}
\hline Year & $\begin{array}{c}\text { No. of } \\
\text { Labour } \\
\text { Force ('000) }\end{array}$ & $\begin{array}{c}\text { No. of } \\
\text { Employed } \\
\text { Person ('000) }\end{array}$ & $\begin{array}{c}\text { No. of } \\
\text { Unemployed } \\
\text { Person ('000) }\end{array}$ & $\begin{array}{c}\text { Unemployment Rate } \\
\text { (Percentage) }\end{array}$ \\
\hline 2011 & $12,675.80$ & $12,284.40$ & 391.40 & 3.1 \\
2012 & $13,119.60$ & $12,723.20$ & 396.40 & 3.0 \\
2013 & $13,634.60$ & $13,210.00$ & 424.60 & 3.1 \\
2014 & $13,931.60$ & $13,532.10$ & 399.50 & 2.9 \\
2015 & $14,518.00$ & $14,067.70$ & 450.30 & 3.1 \\
2016 & $14,710.60$ & $14,202,00$ & 580.50 & 3.5 \\
\hline
\end{tabular}

(Source:Labour Force Statistics Malaysia, 2016; Department of Statistics Malaysia,2016)

The high unemployment rate will reflect poor economic condition in our country due to high number of employees' turnover. According to Wills Towers Watson (2013), they have conducted survey to show that the turnover rate in financial services industry Malaysia has increased significantly from $7.4 \%$ in 2012 to $13.3 \%$ in 2013 . The economic become worst as all financial services industry are practicing cost-efficient in order to compete with the current challenging landscape, which focusing on reducing 
their workforce to an optimal level (The Star Online, 2015). For instance, RHB Capital Berhad has been exercising rightsizing by offering 17,500 employees a career transition scheme (CTS). This is because the globalization has encouraged all the banking industry to change their operations and management styles. In order to compete in the challenges environment, all the banking industry has to provide effective and efficient service to their customer. For instance, installation of Automated Teller Machine (ATM), Cash Deposit Machine (CDM), Cheque Deposit Machine (CQM), Passbook Update Machine, e-banking, and so forth. All the electronic equipment's is easier and more convenient for customer to conduct their transaction in anytime and at anywhere they are instead of walk-in to bank counter. However, the changes of banking industry operations and management styles indirectly will affect the employees' turnover intention as they found out the job might be unsecure anymore.

According to Hussain, Yunus, Ishak, and Daud (2013), the turnover intention of employees will affect the productivity and strategic planning of the organizations. Besides that, the cost of the organizations is increased as they have to incur cost for recruitment and selection, provide training and development of skills and knowledge, to new employees. However, the recruitment cost and time consuming to select the right candidates will be a challenge for an organizations. As well say that every single ringgit saves is every single ringgit earn. Based on the research of Shukla and Sinha (2013) stated that the high turnover rate is problematic and have a negative impact on an organization performance. This is due to the talented employees may leave the organizations and join on competitors organizations. 
Generally, the employees in banking industry are expected to perform high engagement in order to achieve organization's goals, which is focus on the sales volume of the products and services. Moreover, the workload in banking industry is high and it is stringent time frame for employees to complete the tasks. For example, the normal working hour is from $8.45 \mathrm{am}$ to $5.45 \mathrm{pm}$. However, the employees are being required to stay back in order to complete the reporting. Besides that, some employees in branch outlet are required to facilitate the loading and unloading of Automated Teller Machine (ATM), Cash Deposit Machine (CDM), Cheque Deposit Machine (CQM) and other banking facilities during weekend and public holidays. Therefore, the high volume of workload and uncertainty of working hours will caused the employees planning to leave the organization and number of employee's turnover intention will increase accordingly.

Few researches were conducted to study the factors of turnover intention among the employees under banking sector in Malaysia by Keni, Muthuveloo, Teoh and Rubiah Rahman (2013); in Pakistan by Sattar and Ahmed (2014); and in Bangladesh by Rahman and Iqbal (2013). They found out the main factors caused employees to leave is the employee relations, working environment and conditions, compensation and benefit packages, and career advancement opportunities. Therefore, a research should conduct in order to minimize the employees' turnover intention in banking industry in future. 


\subsection{Statement of the Problem}

The voluntary employee turnover is a challenge for all industries around the worldwide (Chen, Friedman, \& Simons, 2014). This phenomena also happening in Malaysia that the management teams are failed to deal with high number of employee turnover, which are including banking industry. This is because the employee turnover is not determined by a single problem but by a cluster of factors (Kossivi, $\mathrm{Xu}$, and Kalgora (2016). The government department has been tracking and highlighted the employee turnover intention trend for the public and organization attentions in order for them to take the necessary action to reduce the turnover rate.

As shown in Table 1.2, the number of employee voluntary termination for 7,070 people out of total 14,138 people from their respective organizations for half-yearly quarter of 2016 (MOHR, Department of Labour of Peninsular Malaysia, 2016). Furthermore, The Sun Daily Online (2016) reported a total of 31,476 employees were laid off between Jan and September of 2016 and Deputy Human Resources Minister Datuk Ismail Abd Muttalib added that 14,425 or $45.8 \%$ of employees is voluntary termination under Voluntary Separation Scheme (VSS) as the employees received better compensation than the legal provisions.

Table 1.2

Number of Employees being Terminate from Jan-Jun 2016

\begin{tabular}{lccc}
\hline & Male & Female & Total \\
\hline Involuntary Termination & 4,274 & 2,794 & 7,068 \\
Voluntary Termination & 3,510 & 3,560 & 7,070 \\
Total & 7,784 & 6,354 & 14,138 \\
\hline
\end{tabular}

(Source: MOHR, Department of Labour of Peninsular Malaysia, 2016) 
Hofhuis, van der Zee, and Otten (2014) mentioned that the strong dissatisfaction over one or more job aspects will cause the employees decide to leave their current job. For example, poor employee relations, poor working environment and conditions, mitigate compensation and benefits packages, as well as reducing the career development opportunities of employees (Kossivi et al., 2016; Leblebici, 2012; Samgnanakkan, 2016). Consequently, the low job satisfactions will increase the employee turnover intention.

Based on the studied of Choi, Ajagbe, and Tan (2013), the employee relations is very important for an organization in order for them to maintain a healthy working relationship between the management team and employees. The healthy relationship will enable both parties to work hand-in-hand to achieve organization goals. Besides that, the healthy relationship also will encourage and increase the motivation of employees to contribute and loyalty to the organizations. Generally, the employee's point of view on organizations is also depending on their relationship with supervisor and colleagues (Kossivi et al., 2016). The employee relations are showing the degree of loyalty from an employee to a particular organization (Kim, Tam, Kim \& Rhee (2017). The studied of Choi and Panniruky (2014) supported that the employee relations management is significantly related to employee turnover intention. According to Lee, Chen, Wang and Dadura (2010) studies found out that the employee relations is the main cause of turnover behaviors of employees. The poor employee relations between both parties will lead the employees decided to leave as they are dissatisfied with their current jobs (Shukla \& Sinha, 2013). 
Moreover, the conducive working environment and conditions are appears to be an essential factor for employee turnover intention (Kossivi et al., 2016). Generally, all employees whom work in banking industry are feeling stressful due to the working environment and conditions. This is because the employees are being required to be able to handle multi-task. Sometimes, they have to work beyond the normal working hours or in duty on public holidays in order to meet customer expectations. On top of that, the technology has made tremendous that affected banking industry. Nowadays, the customers are able to conduct their transaction in anywhere and anytime as the banking function had changed from traditional banking to universal banking. The universal banking includes normal banking functions and other financial services such as investment, insurance, mortgage, securitization, and so on (Kaur, 2015). Therefore, changing banking business environment throughout the world will increase the workload of employees and the time frame for employees to complete the tasks is stringent.

Furthermore, the working conditions may present lack of safety, health and comfort problems such as improper lightening and ventilation, excessive noise, and so on (Leblebici, 2012). Most of the employees are unwilling to work in poor working environment such as lack of tools and equipment to perform their daily transaction (Shukla \& Sinha, 2013). The poor working environment will happen when the banking system is down during the working hours. Therefore, it will affect the productivity of employees as well as will extend the working hours in order to ensure the transaction can be completed in the same days according to Services Level Agreement (SLA) of organizations. Consequence, the employees have to handle and explain to the customer because all the transaction is being interrupted by the poor banking system. Sometimes, 
the employees may be scolded by the frustrated and emotional customer. According to Khan and Aleem (2014) stated that the working environment and conditions is the superior predictors of employee decide to leave the organization voluntarily. This is because the employees are dissatisfied with their current working environment and conditions. Hence, the poor working environment and conditions indirectly will increase the employee turnover intentions.

Besides, the element of compensation and benefits is playing a vital role in the retention of talented employees (Samgnanakkan, 2016). This is because the attractive compensation and benefit packages will encourage and motivate employees to stay in organizations. Vice versa, low salary and restricted benefits will increase the employees turnover rate (Sattar \& Ahmed, 2014). Nowadays, the job hunters are focus on the element of compensation and benefits that offer by the organizations. From the reearch of Sattar and Ahmed (2014), they have found that the high employee turnover rate is due to the low salary and restricted benefits. Therefore, the employees will decide to leave the organizations in order to get high pay job with similar tasks in new organization. According to Khan and Aleem (2015), better pay and fringe benefits can reduce the number of employee's turnover as the organization is able to retain the right workforce for long period of time. Therefore, the human resource management should more creative on rewards system in order to tailoring the right rewards to the right people as nowadays increasing diversity of workforce (Samgnanakkan, 2016).

The Malaysian Employers Federation (MEF) executive director Datuk Shamsuddin Bardan mentioned that the living wage is unsuitable for adoption in Malaysia as the government have introduce several new policies such as Employment 
Insurance System (EIS) that caused employers unaffordable to offers increment to employees due to increasing of operation costs (The Sun Daily Online, 2018). According Lee, Kee, and Tan (2012) stated that extrinsic rewards are more importance compare with intrinsic rewards. This is due to the participation of generation-Y workforce in the job market are preferred on extrinsic rewards, which include the salary, bonus, and other benefits. This scenario will let the senior executive have bad impression on generation $-Y$ as they are too realistic and will not loyalty to the organizations (Ching \& Kee, 2012). Generally, the changed of global economic caused the Gen-Y focus on extrinsic rewards of the organization in order to support for their lifestyle.

Based on data from Statistics Departments Salaries and Wages Survey Report 2016 stated that most Malaysian employees are still paid significantly lower than the desired amount in order to achieve minimum acceptable living standard (The Sun Daily Online, 2018). According to the Employees Job Happiness Index 2017 survey results shown that one out of three (29\%) of Malaysian employees are expressed their thirst for rewards (JobStreet.com, 2018). The turnover rate will increase if the employees are dissatisfied with the compensation and benefit packages that offer by the organization. Moreover, the employers are unaware that satisfaction on compensation and benefits are strongly correlates with employees' decision to stay in the organizations (Kossivi et al., 2016). Hence, the salary bands and compensation as well as benefits pattern should changes and focuses on employee performance and targets rather than experience and loyalty (Kaur, 2015). This is because the compensation and benefits packages will indirectly affect the decision of employees to leave the organization. 
Apart from that, career advancement opportunities will increase employee's commitment to stay in an organization (Kossivi et al., 2016). According to Samgnanakkan (2016), the career advancement opportunities involve an organized, formalized, planned effort to achieve a balance between the individual's career needs and the organization workforce requirements. According to Shukla \& Sinha (2013), the career advancement opportunities will enable the employees to understand their worth of his or her career prospects. The organizations will provide training and developments program for employees to enhance their existing skills and knowledge in order for them to increase their ability and responsibility (Boyer, 1996). This is because the employees can identify various ways to improving their existing processes and systems in order to meet customer requirements and satisfactions. Hence, employee turnover will reduce if organizations are able to provide them career advancement opportunities. Latif, Shahid and Sohail (2011) found out that career advancement opportunities are also one of the important aspects of an employee career prospects. This is because some employees might enjoy the increase in authority over co-workers that often accompany a promotion. The barrier on promotion and training opportunities is the causes of talented employees decide to quit the organization (Shah \& Jumani (2015); Khan \& Aleem (2014).

The studies of Choi and Panniruky (2014) show that the dissatisfaction on employee relations, working environment and conditions, compensation and benefit packages, and career advancement opportunities are significant and directly affected the employees' turnover intention decision. Hence, this research on employee turnover intention should be conduct in order to help the organizations and related parties to reduce the number of employees turnover. 


\subsection{Research Questions}

Below is the list of questions that covered in this research:

i. Do employee relations influence turnover intention?

ii. Do working environment \& conditions influence turnover intention?

iii. Do compensation \& benefit packages influence turnover intention?

iv. Do career advancement opportunities influence turnover intention?

\subsection{Research Objectives}

Below are the objectives of this research in order to identify the causes of turnover intention among bank employees:

i. To examine the relationship between employee relations and turnover intention.

ii. To examine the relationship between working environment \& conditions and turnover intention.

iii. To examine the relationship between compensation \& benefit packages and turnover intention.

iv. To examine the relationship between career advancement opportunities and turnover intention. 


\subsection{Significance of the Study}

This research project plays significance role to identify the factors of employees' turnover intention in banking industry that located in Kuala Lumpur, which include the employee relations, working environment and conditions, compensation and benefit packages, and career advancement opportunities.

Practically this study will support the management team to identify the employee's dissatisfactions on the existing job and organization in private or public sector. Therefore, indirectly it can help the banking industry management team as well as the human resources department to take the appropriate measurement and prevention action in order to reduce the employees' turnover intention in their respective organizations. In long-term period, it will increase the employees' motivation and productivity as well as to reduce the operational costs. Apart from that, this study also can help them to identify the ways of improvement on the employee relations in order to keep the employees loyalty to the organizations.

Theoretically, this study will provide valuable insight information of turnover intention to the researchers in order for them to understand the reason behind the high turnover intention trend among the bank employees in Kuala Lumpur, Malaysia. In addition, this study also provides overview of banking industry such as the working environment and practices, compensation and benefit packages, and career development opportunities to the existing or future researchers in order to assist them to conduct an effectiveness research. 


\subsection{Scope of Study}

The study of turnover intention among the bank employee's is focus on the banking institutions that located nearby Masjid Jamek areas, Kuala Lumpur as most of the head office and branches of the banks is located there. Hence, the employees of banking institutions being selected to participate for this survey are OCBC Bank (M) Berhad, United Overseas Bank (M) Berhad (Medan Pasar Branch), and CIMB Bank Berhad (Menara UAB Branch). This is because the researcher is able to collect different opinion from the employees who are working in local and foreign banking institutions as well as from head office and branches and they are from different backgrounds as well.

\subsection{Definition of Key Terms}

Table 1.3

Definition of Variables

\begin{tabular}{ll}
\hline \multicolumn{1}{c}{ Variable } & \multicolumn{1}{c}{ Definition } \\
\hline Turnover Intention & $\begin{array}{l}\text { The desire of an employee to leave their } \\
\text { current workplace voluntarily } \\
\text { (Wang, 2014). }\end{array}$ \\
Employee Relations & $\begin{array}{l}\text { Interpersonal relationships among the } \\
\text { people in organizations } \\
\text { (Irfann Ismail \& Tan, 2011). } \\
\text { The existing circumstances affecting } \\
\text { employees in the organization }\end{array}$ \\
& $\begin{array}{l}\text { (Irfann Ismail \& Tan, 2011). } \\
\text { All forms of financial rewards that receive } \\
\text { bompensation \& Benefit Packages } \\
\text { baringee as part of an employment } \\
\text { relationship (Wang, 2014). } \\
\text { Ongoing process through a series of stages } \\
\text { for employees development and career } \\
\text { prospects (Rahman \& Nas, 2013). }\end{array}$ \\
\hline
\end{tabular}




\subsection{Organization of Thesis}

The main contents of this thesis are divided into five major chapters as below:

The first chapter is briefs about the overview of the research study. The overview described about the background of the study, statement of the problem, research questions, research objectives, significance of the study, scope of study, definitions of key terms, and organization of thesis.

Next, the second chapter describes about the literature review of the study. This chapter reviews and discusses the previous research, which includes the theories, principles and concepts from other studies that related to the factors that affect the employees' turnover intention in the organization such as employee relations, working environment and conditions, compensation and benefits packages, and career development opportunities. Moreover, this chapter also includes the research framework and hypotheses develop for the research.

The third chapter discusses the research design, data collection methods that describe how the researcher identify the sources of data collection, sampling design that use to identify the target respondents, and also the research instruments to collect the primary data such as the detailed description of the instruments, table of item distribution, and others. A pilot test were conducted to determine the validity and the reliability for the questionnaires instruments as it is adopt and adapt from previous researches. Apart from that, this chapter also discusses the data analysis techniques that including identifying the statistical tools used to analyze the data. 
The chapter four provides the findings of the study. Under this chapter will cover the response rate and analyze the data collection through the distribution of questionnaires to the target populations. Hence, descriptive and inferential unit of analysis are presented in this research. Moreover, statistical results are interpreted and significance of such findings is discussed at the end of research.

Last but not least, the last chapter is the discussion, conclusion as well as the recommendations for this research. The discussion of findings will include the justification of findings, whether the hypothesis is support with literature review. After that, the conclusion and recommendations is to provide general feedback and suggestion for the future researcher to conduct the research under the same problem in order for them to avoid the research limitation. 


\section{CHAPTER TWO \\ LITERATURE REVIEW}

\subsection{Introduction}

This chapter reviews and discusses the theories, principles and concepts of previous research that related to the factors influence the employees' turnover intention in the organization. Besides, this chapter also includes the research framework and develops of hypotheses for this study based on the findings of past researchers.

\subsection{Underpinning Theory}

\subsubsection{Social Exchange Theory}

One of the famous theories that can be used to describe the relationship between employer and employees is social exchange theory (SET). The social exchange theory (SET) was used by many researchers in order to studies the behaviors and attitudes of the employees in workplace. These statements were agreed by Cropanzano and Mitchelll (2005) that the most influential conceptual paradigm to understanding employee behavior in workplace is social exchange theory (SET). Blau (1964) defined the social exchange theory as "favors that create diffuse future obligations, not precisely defined ones, and the nature of the return cannot be bargained about but must be left to the discretion of the one who makes it." In addition, Emerson (1976) stated that the social exchange theory (SET) is about actions that are contingent on rewarding reactions from others. In short, the social exchange theory (SET) is a social interactions and 
interpersonal relations theory. The social relationships will become stronger when both parties are willing to provide valuable resources to the other (Wikhamn \& Hall, 2012).

Usually, the social exchange theory and the norm of reciprocity are used by organizational researchers to understand the motivational basis on employee behaviors and the formation of positive employee attitudes (Settoon, Bennett \& Liden, 1996). According to Cropanzano \& Mitchell (2005) stated that the best known exchange rule of social exchange theory is reciprocity. Therefore, the social exchange theory can be related to human resource management practice such as employee relations, compensation and benefits, career growth, and so on that can influence the employees decision on turnover intentions during the social and economic exchange process.

According to Settoon et al., (1996), the social exchange theory (SET) has been used to explain and describe how the employees are obligated to their supervisors in term of performing in ways beyond the requirement on the formal employment contract. For example, the employer is offering high salaries and better benefit packages as well as training and development opportunities may signal that, organizations valued its employees by investing in their future and career prospects in order to increase inspiration and motivation towards their work and organization. Apart from that, it may also indicate the trust, recognition and appreciation of employee's long term worth. Therefore, the turnover rate is decrease. Vice versa, poor compensation and benefit packages with barrier of career advancement opportunities in an organization is the causes of employees planning to look for new career and decide to quit from the organization accordingly. 
Additionally, most of the employees are not willing to work incredibly if one of their colleagues is doing nothing at workplace and the management team does not take action against him or her. This scenario indirectly will let the employees feel unmotivated and decide to leave their organization. The situation become worst if there is argument among the employee or employer, indirectly employee relations is being affected. Moreover, without the conducive working environment and conditions like lack of safety and health provision, and tool and equipment will cause employees turnover increases.

The social exchange theory (SET) assume that all human being relationships is shaped with human resource management practices that transfer strong messages to individual what an organization expecting from them, afterwards, the reciprocally employees will feel obligation and more committed and decision to remain in the organization. Hence, the management will get the benefit from the social exchange relationship between them and the employees, if they are take care and consent their employees wellbeing. This is because the social exchange relationship is a mediator or intervening variable for employees to produce effective work behavior and positive employee attitudes in workplace (Cropanzano \& Mitchell, 2005). 


\subsection{Variables of the Study}

\subsubsection{Turnover Intention}

The turnover intention of employees have alert the senior management to focus and monitor seriously on the increasing trend of turnover due to the major impacts to the organizations long-term plan and sustainability (Keni et al., 2013). Based on the study by Qasim, Javed, and Shafi (2014), the turnover is meant that the individual estimated probability of leaving the organizations. It is agreed by Rahman and Nas (2013) that the turnover as an employee's permanent movement beyond the boundary of the organizations. According to Khatri (1999), turnover is shifting job regularly or frequent movement of profession from one place to another place without any specific motive. However, Khatri, Budhwar, and Chong (1999) found that the people who change the job is due to they have an itch to try new things or even simply for fun. Apart from that, some people change jobs is influenced by their colleagues (Keni et al., 2013). The employees' turnover can be voluntary or involuntary in form of those who resigns, layoffs, terminates, retires, and so on. Bigliardi, Petroni, and Dormio (2005) stated that the employee who is voluntary to leave the organization is due to the dissatisfaction with some aspect of the work environment or organization such as the co-workers relations, poor performance or attendance, and others. This is a normal psychological response from employees to specific job or organizational conditions and end up with the turnover intention from them (Slatten, Svensson, \& Svaeri, 2011). Lee and Liu (2007) defined that the turnover intention as the conscious from employees and volitional willingness to leave the organization as it is also represents a widespread phenomenon with potentially costly implications for organization (Kosloesky, Weisberg, Yaniv, \& Speiser, 2012). 
Nowadays, many of the young generation employees are known as "frequent employment changes" or "job hoppers" (Hussain et al., 2013). This is because they like to changes the employment frequently. Menefee and Murphy (2004) have studied the main reason for young generation employees to having high level of turnover intention is because dissatisfaction on compensation and benefits, dissatisfaction on management, inadequate opportunity for career-related skill development, uncomfortable work environment, and others. Therefore, studying the behavior of employees enable the senior management to reduce or minimize the turnover rate (Saeed, Waseem, \& Sikander, 2014).

Furthermore, previous studies were conducted by Sattar and Ahmed (2014) stated that the main factor of turnover intention among the bank employee in Pakistan is the work environment. In addition, this statement was supported by Shukla and Sinha (2013) studies that the work environment factor is the main causes of turnover intention for bank employees in India. Besides, the studies of Rahman and Iqbal (2013) shows that $52.08 \%$ of the employees dissatisfied and $6.25 \%$ employees strongly dissatisfied on their career advancement opportunity in Bangladesh commercial banks. Moreover, there are other reasons or factors that lead the employees voluntarily to leave an organization is because of the opportunities for training and career development, compensation and benefit packages, and poor management as well (Rahman \& Nas, 2013).

The employees' turnover intention has positive and negative impact to the organizations. The negative impact on high turnover intention of employees can cause the organization to wasting their money, time, and even productivity (Afif, Sanjay, \& Matloub, 2015). Normally, the organization have to consider on the three basic 
components for employees turnover costs, which are including the separation costs, replacement costs, and training costs (Rahim \& Cosby, 2016). However, it is good for organization to replace productive employees which can bring innovative idea and solution for organizations (Saeed et al., 2014). Therefore, it is important for the organization to obtain the right and best employee to be with their organization especially in banking industry in order to expand their business and maintain their goodwill (Keni et al., 2013).

\subsubsection{Employee Relations}

Generally, our government has implemented various laws in order to govern and ensure the harmonious relationship between the employers and employees in Malaysia that including the Industrial Relations Act 1967 and Trade Union Act 1959. Besides that, the purposes of the laws also use to safeguarding the legitimate rights and interests of both parties. This is because the good relationship among the employers and employees is important for an organization to success. Gill (2008)) agreed that the main key for an organization to success is good employee-management relationship. Therefore, the power distance should be minimizing in the organizations as the employer can try to understand the employee's needs in order to support them. For instance, the employer will provides certain number of investments in developing and motivate their employees. Meanwhile, the employees are willing to give a certain unimportant values such as feelings and time in order to support the culture in workplace (Keni et al., 2013). Indirectly, this phenomenon caused the employees feel obliged to repay the organizations with extra effort and loyalty (Choi et al., 2013). 
Apart from that, the autonomy from the direct supervisor to the employees also will motivate them to work hard and assist organization to meet its objectives and goals. According to Tansel and Gazioglu (2014) stated that there must be a balance of autonomy for employees in their work domain versus hierarchical control by management. The autonomy is referring to the authorization from their respective supervisor to employees in order for them to manage and perform their routine tasks according with their ability and creativity (Shukla \& Sinha, 2013). On top of that, the authentic leadership style will also construct the positive forms of leadership in order to develop trust and positive working environments as well as can foster employee retention (Azanza, Moriano, Molero, \& Mangin, 2015). Besides that, the authentic supervisor will enhance the employees' engagement by promoting hope, trust, optimism, and positive emotions.

Additionally, the communication also plays an important role. This is because openness communication is the best ways to transfer or communicate ideas and information with employees, especially for the top and senior management. The openness communication can cultivate the trust between each other. According to Ntalianis, Dyer, and Vandenberghe (2015) stated that frequent communication between the employer and employees can cause the employees are likely to develop long-term relationships based on shared values and mutual trust. The most common communication channels include notice boards, letter to individuals, newsletters, employee handbooks, monthly magazine, or e-mail and so on (Chew \& Goh, 1997). The effective communication tools can transfer the message clearly and make them feel that organization is always with them on decision making. Furthermore, Hussain et al., (2013) 
have found that the employee engagement are reducing and could possibility leading to feeling of intention to leave. Harter, Schmidt, and Hayes (2002) defined the employee engagement as an individual involvement, satisfaction and enthusiasm for work. The Sun Daily Online (2016) stated that there are ten organizations who have won the Aon Best Employers 2016. This is because they are being observed as high employee engagement, effective leadership, compelling employer brand and high performance culture by Aon Hewitt.

Besides, the quality of working relationship with colleagues is important for the organizations (Irfann Ismail \& Tan, 2011). This is because the poor relationship with colleagues and without co-worker support will demotivate the employees and end up they will leave the organization. According to Sajjad, Amina, Wang, Nadia, and Quang (2016), they defined co-worker support as social rewards among the employees with supportive and helpful colleagues that cooperate and complete the task with each other as a team in the workplace. Indirectly, the harmony relationship is plays an extensive role in a worker's loyalty, commitment, exchange ideas or practices and behaviors in the organizations (Sajjad et al., 2016). Vice versa, the poor relationship will reduce the employees productivity and longer the working hours as well as will increase the customer dissatisfaction towards the services. Hence, Choi et al., (2013) stated that the employee relations is important in order to maintaining a healthy working relationship between the management team and employees as well as the colleagues in order to contribute and to sustain the productivity, motivation, and high morale work environment that enhance job satisfaction for the employee and meet the organization objectives. 


\subsubsection{Working Environment and Conditions}

Every employee would like to have a conducive working environment (Javed, Balouch, \& Hassan, 2014). Hence, the location of workplace is one of the elements that consider by employees during searching for their new career. This is because most of the employees will prefer to stay nearby the organization that connect with the public transport such as Light Rapid Transit (LRT) and bus RapidKL as it is convenience for movement and also can avoid traffic jam. Besides that, other elements that consider by employees is the noisy level, fresh air, refreshment and so on as it is important for employees to decide whether to stay or leave the organizations (Javed et al., 2014). As we know that most of the employee is prefer to working under air-conditional environment such as banking industry as it is conducive and peaceful compare to construction industry.

The employees are unwilling to stay in poor working environment such as on the aspect of safety and healthy provisions as well as do not have appropriate tools and equipment for employees to complete their tasks (Shukla \& Sinha, 2013). Therefore, most of the organization will focus on the employees work related safety and health provision, which involve the illness and disease that cause by their occupational (Blom \& Aronsson, 2010). The initiative take by organizational to shows that they are caring on the employees safety and health provision are including purchasing insurance and providing medical as well as optical benefits to their employees. Furthermore, the organizational will prepare all the necessary tools and equipment for employees such as employee handbook, stationary, access card and others before employees officially joining. 
On top of that, the increasing of workload or job burnout due to the mergers and acquisitions is causing most of the employees stressful as the working environments are dynamics, competitive, and rapidly changing (Sattar \& Ahmed, 2014). A research by Choi, Cheong, Kiju, and Feinberg (2012) defined the job burnout as the state of psychological strain due to the chronic job stress. This is because the business environments are changing rapidly and customer are too demanding on the level and quality of services. Usually, the customer will request for fast turnaround time and convenience services with lower charges and fees. These phenomena are facing by all services industry, which including the banking industry as well.

Apart from that, introduction of new technology and new procedure in the organizations is also the changes on working environment (Irfann Ismail \& Hong, 2011). This may due to the employees are being required to learn the new technology and practices new procedure. Moreover, the employees are request to extend their working hours in order to complete their tasks. Therefore, the employees have to sacrifice their time and energy, which these phenomena will cause work-life imbalance (Keni et al., 2013). Pasamar and Valle (2013) defined the work life balance as satisfaction and good performance at work as well as at home with a minimum of role conflict. This is because the diversification of the workforce and increasing number of women employees or dual-career couples that will blurring of boundary between their career and family which caused by the work environment (Thomas \& Parveen, 2012). According to Hassan (2014), quality of work life is a key predictor for turnover intention and turnover decision. 
Based on the studies of Slatten et al., (2011) stated that building on the service excellence is important for the employees whom work under service industry. This is because the organization can retain the excellence service employees and delivering excellent service quality to customers. In order for an organizational to retain the talented employees, they must provide better working environment and conditions which will enable them to perform well and also can increase their job-satisfaction (Javed et al., 2014). It is agreed by Hassan (2014) that working outcomes are directly interlinked with working environment and conditions.

\subsubsection{Compensation and Benefit Packages}

In the modern world, the changing of traditional compensation and benefit packages is needed in order for organizations to stay in competitive environment (Zhou, Qian, Henan, \& Lei, 2009). The job-seekers will choose to work with the organizations that offer better compensation and benefit packages to them even slightly higher rate of pay or better benefit packages (Sattar \& Ahmed, 2014). Therefore, a strong employer brand plays a major role for job seekers to differentiate their organization from each other and create a competitive advantage for organizations (Alder \& Ghiselli, 2015). From the research of Osibanjo, Adenjji, Falola, and Heirsmac (2014) shown that the determination of the willingness of employees to stay in the organizations is the compensation and benefit packages. The result of the dissatisfaction of employees on the compensation and benefit packages may lead to low performance, increasing degree of absenteeism, and employee turnover (Yaseen, 2013). 
According to Chepkwony (2014), reward systems is concern with the formulation and implementation of strategies and policies for purpose of reward people fairly, and consistency in accordance to the values of the organization. The reward systems include both of the intrinsic and extrinsic rewards that employees receive for performing the jobs (Martocchio, 2015). Intrinsic compensation is refers to employees' psychological mind-sets that result from performing their jobs. For example, recognition and feedback will lead employees be more motivation (Yaseen, 2013). The extrinsic compensation includes both monetary and non-monetary rewards. For monetary rewards is the salary or wages and bonus, meanwhile, the non-monetary rewards are also known as employee benefits such as maternity leave, annual leave, retirement or pension plan, insurance benefits, and so on . According to Ramzan, Hafiz Zubair, Ali and Arslan (2014) defined compensation and benefit as the output that received by employees of their contributions to the organization.

Besides that, the research of Rizal, Syafie Idrus, Djumahir, and Mintarti (2014) found that the organization goal is to give employees welfare by providing compensation to retain and encourage employees to work. Therefore, government have implemented the Minimum Wage Order in 2012 and revised on 2015; which the minimum wage for private sector employees in Peninsular Malaysia is RM900.00 and will increase to RM1,000.00, and from RM800.00 to RM920.00 for the employees in Sabah, Sarawak, and Labuan in order to protect the welfare of the employees, (Singh, 2016). Nowadays, most of the young generation employees are increasing the job mobility in market due to most of them attempt to find a better salary and fringe benefits in order to cope with sophisticated lifestyle and economic inflation (Queiri, Wan 
Fadzilah Yusoff, \& Dwaikat, 2015). Hence, the employees are to be encouraged to stay with employer that offers even a considerably higher rate of pay and benefit packages (Sattar \& Ahmed, 2014; Shukla \& Sinha, 2013). Furthermore, a study on young generation employees' turnover shows that $38.20 \%$ employee stated that the satisfaction with pay and fringe benefits has the strongest effect for them on the decision to leave the organizations (Queiri et. al., 2015).

\subsubsection{Career Advancement Opportunities}

As a senior management of the organizations, they must be able to understand and realize that every employee is motivated by a different set of needs. One of the motivation models that identified by Abraham Maslow (1954) is known as Maslow's hierarchy of needs model, which are compound 5 distinct needs. The distinct needs are from the basic needs physiological, safety, love, esteem, and to the most complex needs as self-actualization (McLeod, 2016). Usually, the employee's needs must be satisfied at one level before ascending to the next level that started from physiological needs and continue to achieve self-esteem and self-actualization needs.

The career advancement opportunities or career development is important for an employee to fulfill their self-esteem needs. According to Osibanjo, Oyewunmi, \& Ojo (2014) defined the career development as an ongoing and formalized effort by an organization that focuses on developing and enriching the organizations human resources in light of both the employee's and the organizations needs in order to achieving the organization goals and objectives. Besides that, the career development also defined as an opportunity to develop the employee's skills and gain access to new 
job position through promotion (Hofhuis et al., 2014). The increment and promotion is important for employees during their career establishment stage (Xie, Xin,\& Bai, 2016).

Figure 2.1

Maslow's Hierarchy of Needs

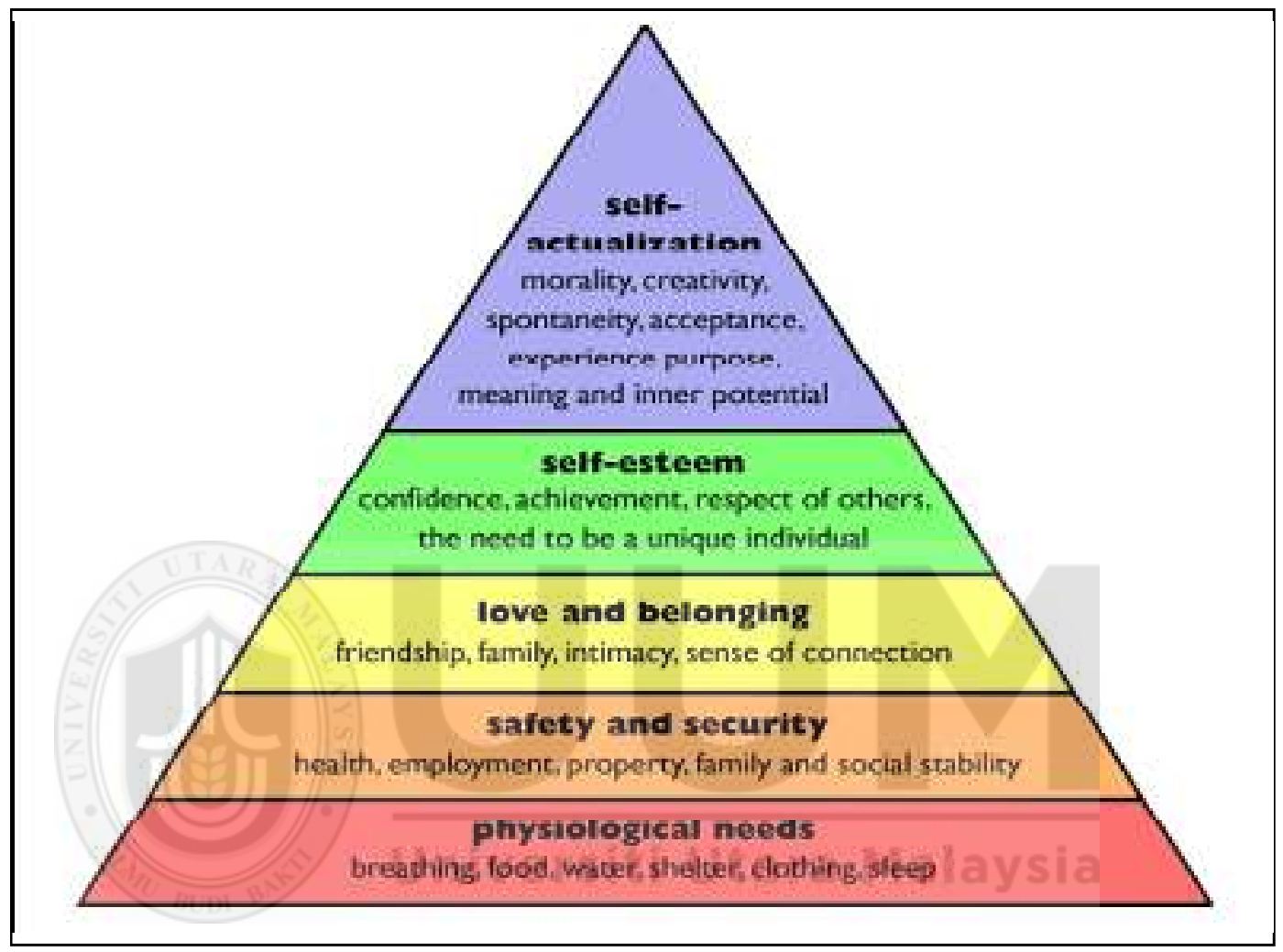

(Sources: McLeod, 2016)

Therefore, the organizations can motivate the employees by promote them or providing various training and development program in order to enhance their existing skills and knowledge to support daily operations (Osibanjo et al., 2014). Moreover, the organizations can nurture and ready the employees to become leaders in the workplace. Hence, the career development can ensure that the organizations will have the suitable candidates with the necessary skills and knowledge to meet the strategic organization goals during the talented employee is leaving. Besides that, the career development also can help employees to perform their current jobs better, helping employees qualify for 
the future jobs, keeping employees informed of changes within the organization, and providing opportunities for personal development (Alipour, Salehi, \& Shahnavaz, 2009). Previous research shows that perceived career opportunities outside the organization and lack of career advancement opportunities inside organization will increase the employee's intention to leave the organization (Hassan, 2014). According to Sattar and Ahmed (2014), the high employee's turnover may due to no prospective chance for progression or promotions. Therefore, the higher turnover intention of employees can affect the organization efficiency and effectiveness (Alipour et al., 2009).

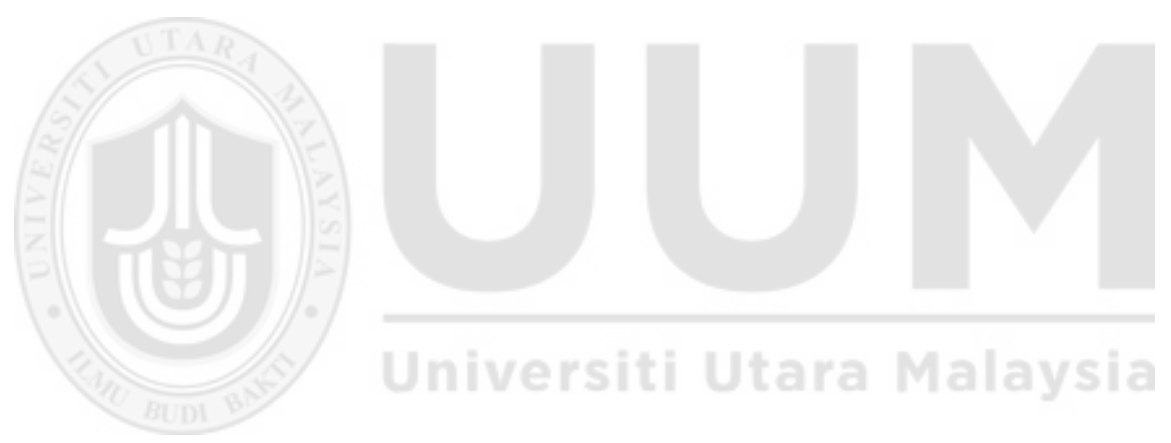




\subsection{Research Framework}

Figure 2.2 shows that the research framework for this study. The aim for this study is to identify the relationship between employee relations, working environment and conditions, compensation and benefit packages, career advancement opportunities and turnover intention. Few of past studies have argued that employee relations (Choi et al., 2012), working environment and conditions (Cohen, Balke, \& Goodman, 2015; Jha, 2009), compensation and benefit packages (Saeed et al., 2014; Rahman \& Iqbal, 2013), career advancement opportunities (Rahman \& Nas, 2013; Shukla \& Sinha, 2013) are impact on employees' turnover intention.

Figure 2.2

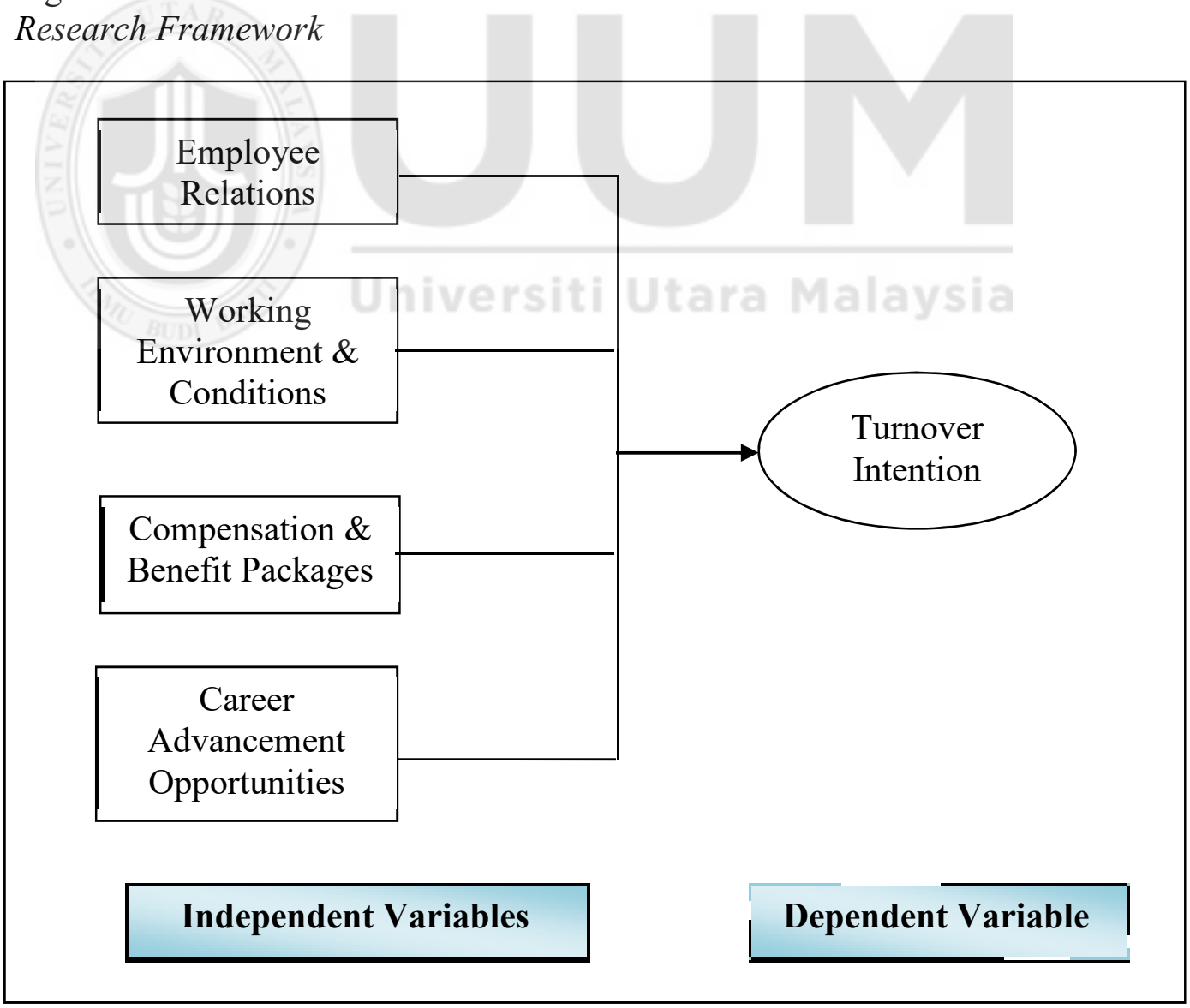




\subsection{Hypotheses Development}

\subsubsection{Employee Relations and Turnover Intention}

According to Shukla and Sinha (2013) studies shows that all level workforce relations plays a vital role on turnover as the poor relationship with the management team and colleagues can be an important reason for the employees to leave their jobs. Furthermore, it is supported by Choi et al., (2013) studies stated that the employees in multinational companies revealed that perceived supervisory support has a direct relation to turnover intention. This is because the good relationship among the employee with management and other colleagues will motivate and provide support to them in workplace. Vice versa, the poor relationship might cause the employees feel hopeless and disappointed in workplace. Additionally, the studies of Rahman and Nas (2013) supported that social support is playing an important role in mitigating the employee's intention to quit from the jobs. Therefore, these arguments suggest the following hypotheses:

H1: There is a negative and significant relationship between employee relations and turnover intention.

\subsubsection{Working Environment and Conditions and Turnover Intention}

The employees can perform well if they are provided good working environment and conditions (Qasim et al., 2014). This is because the working outcomes are direct affected by the working environment and conditions such as the proper lighting, furniture, restrooms, and other health and safety provisions (Sattar \& Ahmed, 2014). Moreover, the employees are not willing to stay in the poor environment for a long time 
period (Shukla \& Sinha, 2013). According to Hassan (2014), the quality of environment and work life is a key predictor for turnover intention and turnover decision. Therefore, the work-life balance provision will indirectly affect the employee's decision to leave the organization, especially for young generation (Queiri et al., 2015). Hence, the hypotheses suggest as below:

H2: There is a negative and significant relationship between working environment and conditions and turnover intention.

\subsubsection{Compensation and Benefit Packages and Turnover Intention}

According to Sattar and Ahmed (2014), the low salary with limited benefit packages is one of the common reasons of high employee turnover rates in an organization. Usually, the job-seekers will choose to work with the organizations that offer better compensation and benefit packages as it is a determination of the employees to stay or leave the organizations (Sattar \& Ahmed, 2014; Osibanjo et al., 2014). The compensation and benefit packages are important for the employees in terms to satisfying their economic needs and it is also the indicator for employees to leave the organization (Hassan, 2014). According to Hassan (2014) studies shows that the employees whom are dissatisfied with their pay level and rewards is likely intention to leave the organization. Moreover, the unattractive compensation and benefit package will unmotivated employees' on job performance as well as to maintain negative attitudes towards the jobs (Choi, Panniruky, \& Ajagbe, 2012). These arguments suggest the following hypotheses: 
H3: There is a negative and significant relationship between compensation and benefit packages and turnover intention.

\subsubsection{Career Advancement Opportunities and Turnover Intention}

Based on the studies of Rahman \& Iqbal (2013), career advancement opportunity is the main causes for employees in private commercial banks $\mathrm{s}$ to switch their job. This statement were supported by Cohen et al., (2015) that career advancement opportunities is the main factor to affect the employees job satisfaction and consequently to turnover intentions. Additionally, a high employee turnover rate is due to no prospective chance for progressions or promotions in the organizations (Sattar \& Ahmed, 2014). These arguments suggest the following hypotheses:

H4: There is a negative and significant relationship between career advancement opportunities and turnover intention.

\subsection{Chapter Summary}

This chapter reviewed and discussed the theory and literature review from previous articles and journals that related to the factors influence the employees' turnover intention in the organization and to construct the research framework. Moreover, the findings of past researchers are used to develop the hypotheses for this research. 


\section{CHAPTER THREE \\ RESEARCH METHODOLOGY}

\subsection{Introduction}

This chapter discusses the methodology uses in the study that includes the research design, data collection methods, sampling design and also the research instruments with the pilot test in order to ensure the trustworthy of the research. Apart from that, this chapter also will discuss the construct measurement for the data collection and the data analysis techniques uses to test the hypotheses.

\subsection{Research Design}

The research design is a master plan that specifies the methods and procedures for collecting and analyzing the needed information (Zikmund, Babin, Carr \& Griffin, 2013). Therefore, the researcher will include the activity and time based plan with the selection of sources and types of information as well as the design outlines procedures for every research activity in their research design (Cooper \& Schindler, 2011).

According to Zikmund et al., (2013), there are 2 types of research design methods, which are consists of qualitative research and quantitative research. The qualitative research is a research that address the objectives through techniques that allow the researcher to provide elaborate interpretations of phenomena without depending on numerical measurement or its focus is on discovering true inner meanings

and new insight, meanwhile, the quantitative research is a research that addresses the 
objectives through empirical assessments that involve numerical measurement and analysis (Zikmund et al., 2013).

This research is applies the quantitative research. This is because the quantitative research method is usually emphasizes quantification in the collection and analysis of data (Bryman \& Bell, 2011). Moreover, the quantitative research method is more appropriate to measure and test the hypotheses from the data collection through the survey approach that involve widespread population. Based on Zikmund et al., (2013), they defined the survey approach as a method of collecting data through the communication with a representative sample of individuals.

\subsection{Measures}

\subsubsection{Turnover Intention}

In this study, turnover intention is defined as "the intention of employees to leave an organization". There are five-items that adapted from Wang (2014). For instance, "I will spend my entire career with this organization" and "I intend to leave this organization within a short period of time". According to Wang (2014) study, the value of Cronbach alpha for this measure is 0.92 . There are 5-point Likert scale range from strongly disagree to strongly agree applied on the questionnaires. 
Table 3.1

Items represent the Turnover Intention

\begin{tabular}{|c|c|c|c|c|}
\hline Variable & $\begin{array}{c}\text { Operational } \\
\text { Definition }\end{array}$ & Number of Item & $\begin{array}{c}\text { Cronbach's } \\
\text { Alpha }\end{array}$ & Sources \\
\hline $\begin{array}{l}\text { Turnover } \\
\text { Intention }\end{array}$ & $\begin{array}{c}\text { "The desire } \\
\text { of an } \\
\text { employee to } \\
\text { leave their } \\
\text { current } \\
\text { workplace } \\
\text { voluntarily" }\end{array}$ & $\begin{array}{l}\text { 1. I will spend my entire career } \\
\text { with this organization. } \\
\text { 2. I intend to leave this } \\
\text { organization within a short } \\
\text { period of time. } \\
\text { 3. I have decided to quit this } \\
\text { organization. } \\
\text { 4. I am looking at other jobs } \\
\text { now. } \\
\text { 5. If I do not get promoted } \\
\text { soon, I will look for a job } \\
\text { elsewhere. }\end{array}$ & 0.92 & $\begin{array}{l}\text { Wang } \\
(2014)\end{array}$ \\
\hline
\end{tabular}

\subsubsection{Employee Relations}

In order to measure employee relations, there are three-items adapted from Irfann Ismail \& Tan (2011) and the Cronbach alpha for this study is 0.787 . For an example, "I have good working relationships with my colleagues", "I have socialized with my colleagues during breaks at workplace" and "My colleagues have helped me in performing my tasks". There are 5-point Likert scale range from strongly disagree to strongly agree applied on the questionnaires.

Table 3.2

Items represent the Employee Relations

\begin{tabular}{|c|c|c|c|c|}
\hline Variable & $\begin{array}{c}\text { Operational } \\
\text { Definition }\end{array}$ & Number of Item & $\begin{array}{c}\text { Cronbach's } \\
\text { Alpha }\end{array}$ & Source \\
\hline $\begin{array}{l}\text { Employee } \\
\text { Relations }\end{array}$ & $\begin{array}{l}\text { "Interpersonal } \\
\text { relationships } \\
\text { among the } \\
\text { people in } \\
\text { organizations" }\end{array}$ & 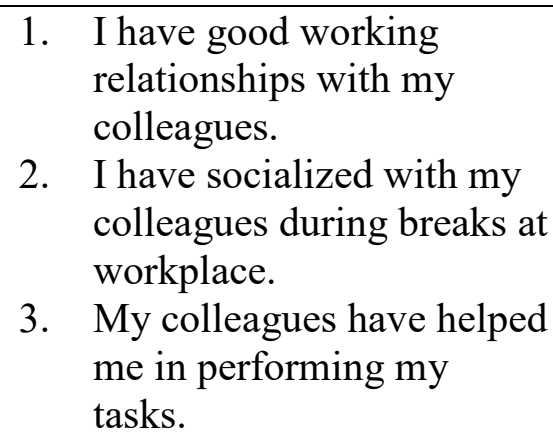 & 0.787 & $\begin{array}{l}\text { Irfann } \\
\text { Ismail } \\
\text { \& Tan } \\
(2011)\end{array}$ \\
\hline
\end{tabular}




\subsubsection{Working Environment and Conditions}

According to Irfann Ismail \& Tan (2011), working environment and conditions was measured with 4-items scale such as "My working conditions are up to satisfactory standards". The questionnaires were adapted by the researcher and the Cronbach alpha for the Ismail and Hong (2011) study is 0.779 . There are 5-point Likert scale range from strongly disagree to strongly agree applied on the questionnaires.

Table 3.3

Items represent the Working Environment and Conditions

\begin{tabular}{|c|c|c|c|c|c|}
\hline Variable & $\begin{array}{c}\text { Operational } \\
\text { Definition }\end{array}$ & & Number of Item & $\begin{array}{c}\text { Cronbach's } \\
\text { Alpha }\end{array}$ & Sources \\
\hline $\begin{array}{c}\text { Working } \\
\text { Environment } \\
\& \text { Conditions }\end{array}$ & $\begin{array}{l}\text { "The existing } \\
\text { circumstances } \\
\text { affecting } \\
\text { employees in the } \\
\text { organization" }\end{array}$ & 1. & $\begin{array}{l}\text { My working } \\
\text { conditions are up to } \\
\text { satisfactory standards. } \\
\text { All required resources } \\
\text { are available to me. } \\
\text { The working } \\
\text { environment is } \\
\text { conducive. } \\
\text { The comfort I am } \\
\text { provided at work is } \\
\text { high. }\end{array}$ & 0.779 & $\begin{array}{l}\text { Irfann } \\
\text { Ismail } \\
\& \text { Tan } \\
(2011)\end{array}$ \\
\hline
\end{tabular}

\subsubsection{Compensation \& Benefit Packages}

The compensation and benefit package is the company effort to stimulate the employees' financial satisfaction. There are 3-items scales that adapted from Wang (2014). Examples items are "I am satisfied with my total income earned" and "I am satisfied with the hourly wage that I receive". The Cronbach alpha for Edward (2014) study is 0.90 . There are 5-point Likert scale range from strongly disagree to strongly agree applied on the questionnaires. 
Table 3.4

Items represent the Compensation and Benefit Packages

\begin{tabular}{|c|c|c|c|c|}
\hline Variable & $\begin{array}{c}\text { Operational } \\
\text { Definition }\end{array}$ & Number of Item & $\begin{array}{c}\text { Cronbach's } \\
\text { Alpha }\end{array}$ & Sources \\
\hline $\begin{array}{l}\text { Compensation } \\
\text { \& Benefit } \\
\text { Packages }\end{array}$ & $\begin{array}{l}\text { "All forms of } \\
\text { financial } \\
\text { rewards that } \\
\text { receive by } \\
\text { employee as } \\
\text { part of an } \\
\text { employment } \\
\text { relationship" }\end{array}$ & $\begin{array}{l}\text { 1. I am satisfied with } \\
\text { my total income } \\
\text { earned. } \\
\text { 2. I am satisfied with } \\
\text { the hourly wage } \\
\text { that I receive. } \\
\text { 3. I am satisfied with } \\
\text { the amount of } \\
\text { recognition that I } \\
\text { receive. }\end{array}$ & 0.90 & $\begin{array}{l}\text { Wang } \\
(2014)\end{array}$ \\
\hline
\end{tabular}

\subsubsection{Career Advancement Opportunities}

The collaborative and consistent effort of employee or employer works with motive to enrich employees' attitudes, knowledge, experiences, skills, and abilities and to improve their overall effectiveness is meant for career advancement opportunities. Based on the Rahman and Nas (2013) study, the Cronbach alpha for the measurement is 0.799. There are 5-items scale by Rahman and Nas (2013), for instance, "Organization developmental efforts have improved my self-awareness, competencies, and employability", " I have made sufficient progress to achieve my career goals" and "Organization management has provided me with adequate resources needed for my development". There are 5-point Likert scale range from strongly disagree to strongly agree applied on the questionnaires. 
Table 3.5

Items represent the Career Advancement Opportunities

\begin{tabular}{|c|c|c|c|c|c|}
\hline Variable & $\begin{array}{c}\text { Operational } \\
\text { Definition }\end{array}$ & & Number of Item & $\begin{array}{c}\text { Cronbach's } \\
\text { Alpha }\end{array}$ & Sources \\
\hline $\begin{array}{c}\text { Career } \\
\text { Advancement } \\
\text { Opportunities }\end{array}$ & $\begin{array}{c}\text { "Ongoing } \\
\text { process } \\
\text { through a } \\
\text { series of stages } \\
\text { for employees } \\
\text { development } \\
\text { and career } \\
\text { prospects", }\end{array}$ & $\begin{array}{l}2 . \\
3 . \\
4 . \\
4 .\end{array}$ & $\begin{array}{l}\text { Organization } \\
\text { developmental } \\
\text { efforts have } \\
\text { improved my self- } \\
\text { awareness, } \\
\text { competencies, and } \\
\text { employability. } \\
\text { I have made } \\
\text { sufficient progress to } \\
\text { achieve my career } \\
\text { goals. } \\
\text { Organization } \\
\text { management has } \\
\text { provided me with } \\
\text { adequate resources } \\
\text { needed for my } \\
\text { development. } \\
\text { Employee } \\
\text { development is } \\
\text { perceived in a } \\
\text { positive way. } \\
\text { Employee } \\
\text { development } \\
\text { decisions are made } \\
\text { in an unbiased } \\
\text { manner. }\end{array}$ & aysïa & $\begin{array}{l}\text { Rahman } \\
\text { \& Nas } \\
(2013)\end{array}$ \\
\hline
\end{tabular}




\subsection{Data Collection Procedures}

Data is playing an important role for every research. The process of collecting data is crucial as the accuracy data will enable researcher to test the research hypotheses. According to Cooper and Schindler (2011), the data can be collect through primary data or secondary data. The primary data is the original data being collected are designed specifically to answer the research question, meanwhile, the secondary data are the studies that done by other researchers in which the data are being reviewed and reused (Cooper \& Schindler, 2011).

The primary data is more valid as all the data being collect from the respondents compared to secondary data. However, the secondary data is cheaper and faster in the process to obtaining the data (Zikmund et al., 2013). The researcher will use primary data for this research. The primary data such as questionnaires was distributed to the employees who are working in banking industry at Kuala Lumpur, Malaysia.

The researcher distribute the questionnaires to the target respondents, which are the bank employees in the banking industry located nearby Masjid Jamek areas such as OCBC Bank (M) Berhad, United Overseas Bank (M) Berhad (Medan Pasar Branch), and CIMB Bank Berhad (Menara UAB Branch) during lunch hours around 12p.m. to 2p.m. and after working hours around 5 p.m. to $7 \mathrm{p} . \mathrm{m}$. This is because these areas involved high number of target respondents which are same working experience and knowledge. The questionnaires giving to respondents' fill-in and return on-the-spot once they have answering because it will take about 10-15 minutes to complete. 


\subsection{Sampling Design}

There are some steps for the sampling designs such as define the target population, select a sampling frame, determine the sampling techniques, and determine sample size (Zikmund et al., 2013). According to Zikmund et al., (2013), the population is defined as any complete group of entities that share some common set of characteristics. Usually, the sample of the research is from the smaller number of population. The sample is defined as a subset or some part of a large population (Zikmund et al., 2013).

\subsubsection{Target Population}

The target population is those people, events, or records that contain the desired information for the study that determine whether a sample or a census should be selected (Cooper \& Schindler, 2011). The target population for this study is the employees in banking industry at Kuala Lumpur, Malaysia that located nearby Masjid Jamek areas, which included local and foreign banking industry like OCBC Bank, UOB Bank, and CIMB Bank. Therefore, the total population of the study is 232 employees as shown in Table 3.6.

Table 3.6

Number of Employees from Respective Banking Institutions

\begin{tabular}{cc}
\hline Banking Institutions & Number of Employees (person) \\
\hline OCBC Bank (M) Berhad & 210 \\
United Overseas Bank (M) Berhad & 9 \\
CIMB Bank Berhad & 13 \\
\hline Total Number of Employees & $\mathbf{2 3 2}$ \\
\hline
\end{tabular}




\subsubsection{Sampling Techniques}

There are two types of sampling techniques, which are probability sampling and non-probability sampling (Zikmund et al., 2013). The probability sampling is a controlled, randomized procedure that assures that each population element is given a known non-zero chance of selection, meanwhile, the non-probability sampling is a nonrandom and subjective procedure where each population element does not have a known non-zero chance of being included (Cooper \& Schindler, 2011).

The probability samplings have four types of sampling, which include simple random sampling, systematic sampling, stratified sampling, and cluster sampling (Zikmund et al., 2013). According to Zikmund et al., (2013), the simple random sampling is a sampling procedure that assures each element in the population have equal chance of being included in the sample; the systematic sampling is a sampling procedure in which a starting point is selected by a random process and then every $n$th number on the list is selected; the stratified sampling is a procedure in which simple random subsamples that are more or less equal on same characteristic are drawn from within each stratum of the population; and the cluster sampling is an economically efficient sampling techniques in which the primary sampling unit is not the individual element in the population but a large cluster of elements or the clusters are selected randomly.

Besides, there are also four types of non-probability sampling, convenience sampling, judgment sampling, quota sampling, and snowball sampling (Zikmund et al., 2013). The convenience sampling is a sampling procedure that obtaining those people or units respond that are most conveniently available; the judgment sampling is an experienced individual selects the sample based on personal judgment about some 
appropriate characteristic of the sample member; the quote sampling is to ensures that various subgroups of a population is represented on pertinent characteristics to the exact extent that the investigator desires; and the snowball sampling is a sampling procedure in which initial respondents are selected by probability methods and additional respondents are obtained from information provided by the initial respondents (Zikmund et al., 2013).

The non-probability sampling method, which is convenience sampling technique applied in this research. The researcher distributes the questionnaire to the target employees in banking industry that located nearby Masjid Jamek areas at Kuala Lumpur, Malaysia. The reason to using the convenience sampling techniques is because it is easy, convenience and economical to get the respond on the questionnaires in large populations as well as to ensure the accuracy of the data collection for this research.

\subsubsection{Sample Size}

As shown in Table 3.6, the total population size for this study is 232 employees. Therefore, a total of 150 questionnaires were distributed to the employees who are working in banking industry at Kuala Lumpur, Malaysia that located nearby Masjid Jamek areas (as suggested by Krejcie \& Morgan, 1970). 
Table 3.7

Table for Determining Sample Size from a Given Population

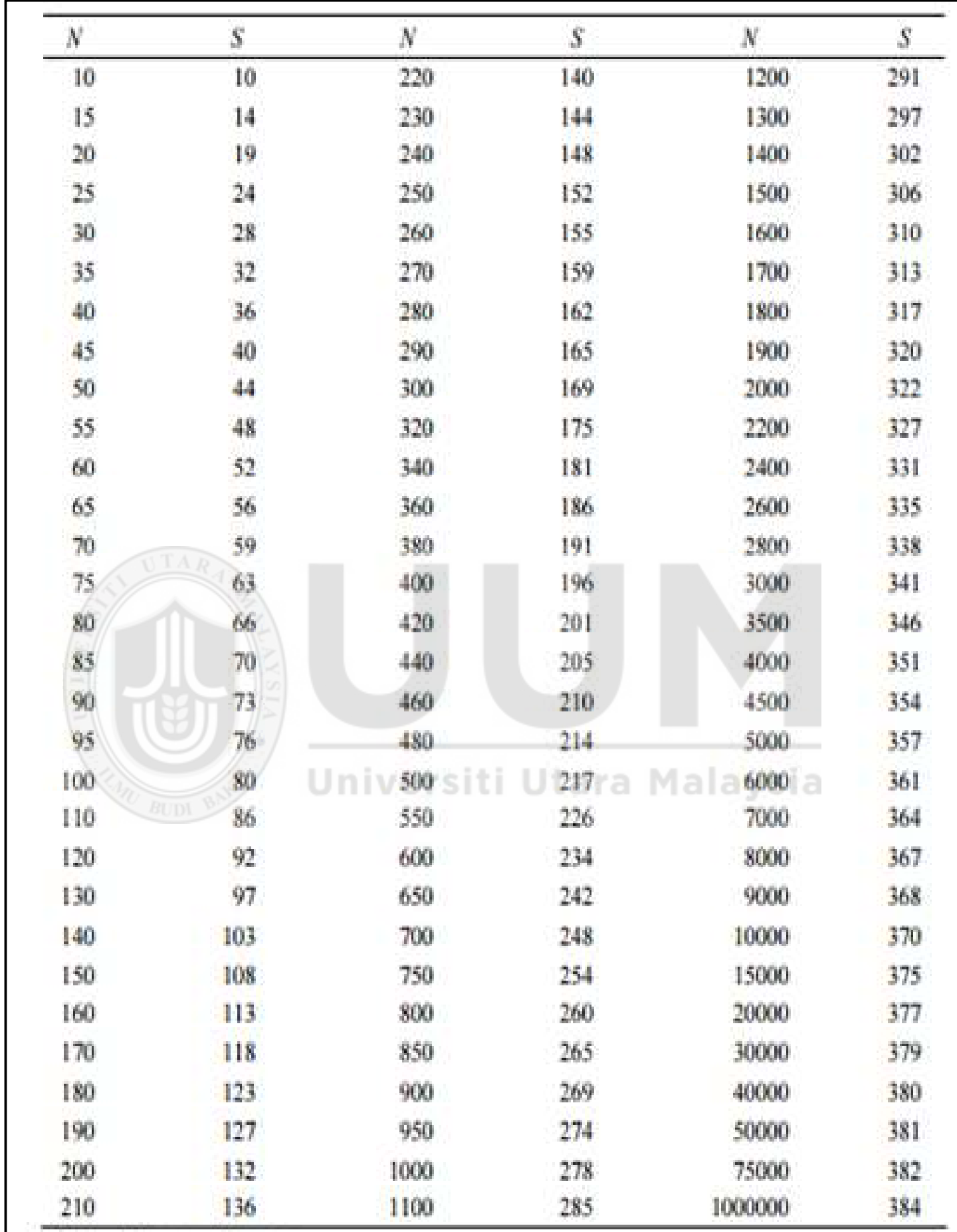

Note.-N is population size.

$S$ is sample size.

(Source: Krejcie \& Morgan, 1970) 


\subsection{Research Instruments}

The researcher will adapt and adopt questionnaires from previous articles to collect primary data. This is because the self-administered questionnaires are cheaper and easy to get respond from the respondents' in short period time (Bryman \& Bell, 2011). The researcher will give out the questionnaire to the respondents by herself with the assistance of friends.

\subsubsection{Questionnaires Design}

There are two types of question design, which are free-response questions or known as open-ended questions and fixed-alternative questions (Zikmund et al., 2013). The open-ended questions is the questions that pose some problem and ask respondents to answer in their own words, meanwhile, the fixed-alternative questions is the questions in which respondents are given specific, limited-alternative responses and asked to choose the one closest to their own viewpoint (Zikmund et al., 2013). For this study, fixed-alternative questions such as multiple-choice answer questionnaires were used. This is because the questionnaire can be distributed to the large population of respondents in a short time period and it is also can reduce the time consuming for respondents to answering the questionnaires.

The questionnaire consists of 25 questions and divided into 3 major sections. The section $\mathrm{A}$ is demographic information, section $\mathrm{B}$ is dependent variable, and section $\mathrm{C}$ is independent variable. The section A questions are designed to get the respondents demographic profile and it consists of 5 questions which are include respondents age, gender, highest education level, length of services, and monthly income level that adapt 
and adopt from Kaur (2015). In section B, there are 5 questions to measure the dependent variable. Besides, the section $\mathrm{C}$ is to measure the independent variables such as employee relations, working environment \& conditions, compensation and benefit packages, and career advancement opportunities variables. The five-point Likert scale is applies on the questionnaire for all the dependent and independent variables in which the respondents are given pre-determined responses in which the questionnaires are rated from strongly disagree to strongly agree combinations.

Table 3.8

Distribution of Variables

\begin{tabular}{|c|c|c|c|}
\hline Variables & $\begin{array}{l}\text { Total No. } \\
\text { of Items }\end{array}$ & Scales & Sources \\
\hline Turnover Intention & 5 & $\begin{array}{c}\text { 5-point Likert scale } \\
\text { (Strongly disagree/agree } \\
\text { combinations) }\end{array}$ & $\begin{array}{l}\text { Wang } \\
(2014)\end{array}$ \\
\hline Employee & 3 & 5-point Likert scale & Irfann \\
\hline Relations & & $\begin{array}{c}\text { (Strongly disagree/agree } \\
\text { combinations) }\end{array}$ & $\begin{array}{l}\text { Ismail \& } \\
\text { Tan }(2011)\end{array}$ \\
\hline Working & \multicolumn{3}{|c|}{4 iversif 5-point Likert scale aysi a Irfann } \\
\hline Environment \& & & (Strongly disagree/agree & Ismail \& \\
\hline Conditions & & combinations) & $\operatorname{Tan}(2011)$ \\
\hline Compensation \& & 3 & 5-point Likert scale & Wang \\
\hline Benefit Packages & & $\begin{array}{c}\text { (Strongly disagree/agree } \\
\text { combinations) }\end{array}$ & (2014) \\
\hline Career & 5 & 5-point Likert scale & Rahman \\
\hline Advancement & & (Strongly disagree/agree & $\&$ Nas \\
\hline Opportunities & & combinations) & $(2013)$ \\
\hline
\end{tabular}

\subsubsection{Pilot Test}

A pilot test on the variables is needed in order to ensure the reliability and validity of the questionnaires which adopted and adapted from previous studies. For this research, 30 set of questionnaires was distributed to the target respondents who working in banking industry at Kuala Lumpur, Malaysia that located nearby Masjid Jamek areas. 


\subsubsection{Outcome of Reliability}

The most common applied estimate of a multiple-item scale's reliability is known as Cronbach's Alpha Coefficient (Zikmund et al., 2013). Therefore, the Cronbach's Alpha was used on this research to measure the reliability level of dependent and independent variables. The result of Cronbach's Alpha for this research is as below:

Table 3.9

Cronbach's Alpha Coefficient Result for All the Variables

\begin{tabular}{lcc}
\hline Dependent Variable & Number of Item & Cronbach's Alpha \\
\hline Turnover Intention & 5 & 0.799 \\
\hline Independent Variables & Number of Item & Cronbach's Alpha \\
\hline Employee Relations & 3 & 0.798 \\
Working Environment \& Conditions & 4 & 0.826 \\
Compensation \& Benefit Packages & 3 & 0.907 \\
Career Advancement Opportunities & 5 & 0.880 \\
\hline
\end{tabular}

According to above result, all the Cronbach's Alpha value for dependent and independent variables shows more than 0.6 , which indicate that all the items in the questionnaires are reliable as below interpretation suggested by Zikmund et al., (2013):

Table 3.10

Internal Consistency for Cronbach's Alpha Coefficient

\begin{tabular}{ll}
\hline Cronbach's Alpha & Internal Consistency \\
\hline$\alpha \geq 0.8$ & Very good reliability \\
$0.7>\alpha \geq 0.8$ & Good reliability \\
$0.6>\alpha \geq 0.7$ & Fair reliability \\
$0.6>\alpha$ & Poor reliability
\end{tabular}

[Sources: Zikmund et al., (2013)] 


\subsection{Data Analysis Techniques}

Once the data collection completed, all the data were filtered in order to segregate those incomplete information data. Therefore, the remaining 120 set of questionnaires were used for analysis purpose by applied the data analysis techniques and Statistical Package for Social Science (SPSS) software version 23 in order to interpret and analyze the quantitative data for this research.

There are two types of data analysis techniques that use to study and analyze the data of the study. Firstly, descriptive statistics is use to summarize and describe the data in a simple and understandable manner (Zikmund et al., 2013). Another type of statistics is the inferential statistics that using statistics to project characteristics from a sample to an entire population in order to test the hypotheses of the research (Zikmund et al., 2013).

The descriptive analysis technique were used to study and summarize the target respondent demographic information's for this research such as age, gender, highest education level, length of services, and monthly income level. Meanwhile, the inferential analysis technique such as Pearson Correlation Analysis and Multiple Regressions Analysis were using to analyze and test the relationship of the hypotheses for this research.

Pearson correlation analysis is used to indicate the correlation of one variable to another (Zikmund et al., 2013). For this research, the correlation analysis was used to examine the relationship of dependent variable and independent variables whether it is strong or weak. The correlation analysis value is ranges from -1.0 indicates perfect negative relationship to +1.0 indicates perfect positive relationship, and, value ' 0 ' indicates that no relationship exist for the dependent and independent variables 
(Zikmund et al., 2013). Table 3.11 described the interpretation of correlation coefficient as suggested by Davis (1971):

Table 3.11

Strength of Correlation Table

\begin{tabular}{ll}
\hline Scales & Relationship \\
\hline $0.10-0.29$ & Weak relationship \\
$0.30-0.49$ & Moderate relationship \\
$0.50-0.69$ & Strong relationship \\
$0.70-1.00$ & Very strong relationship
\end{tabular}

[Sources: Davis (1971)]

According to Zikmund et al., (2013), there are 3 types of statistical analysis to test the hypotheses. Firstly, the univariate statistical analysis is only involving one variable; secondly, the bivariate statistical analysis are involve two variables; lastly, multivariate statistical analysis are involving three or more variables or sets of variables (Zikmund et al., 2013). The bivariate statistics analysis such as multiple regression analysis was used to analyze and interpret the relationship between a single dependent variable and multiple independent variables for this research.

If $\mathrm{p}$-value $=\mathrm{p}<0.05$, there is a relationship between dependent variable and independent variables and the hypotheses is to be accepted. However, if p-value is greater than significance level 0.05 ( $>>0.05)$, there is no relationship between dependent variable and independent variables, thus, the hypotheses failed to be accepted. 


\subsection{Chapter Summary}

Overall, this chapter shows a clear picture on the quantitative research method that used to conduct the research. Besides, the questionnaires and the measurement of each variable are adapted from past studies in order further used for the data collection from the target respondents. In addition, a pilot test has been conducted in order to check the reliability of the research instrument before sending the questionnaires for data collection purpose. Once the pilot test completed, the questionnaires were distributed to the target respondents who work in banking industry nearby Masjid Jamek area, Kuala Lumpur. Furthermore, Statistical Package for Social Science (SPSS) 23.0 and descriptive statistical analysis as well as inferential statistical analysis is used to test the correlation relationship of dependent variable and independent variables as well as the research hypotheses. 


\section{CHAPTER FOUR \\ RESULTS AND DISCUSSION}

\subsection{Introduction}

This chapter presents the findings of the study. The descriptive and inferential analyses were applied by using Statistical Package for Social Science (SPSS) 23.0 for this study. Moreover, the statistical results are interpreted and discussed at the end of research.

\subsection{Response Rate}

A total of one hundred and fifty (150) set of questionnaires were distributed to the bank employees that located nearby Masjid Jamek in Kuala Lumpur, Malaysia. However, there are 120 set of questionnaires were successful collected from respondents and the respond rate is $80 \%$ out of $100 \%$. Please refer Table 4.1 as below:

\section{Table 4.1}

Response Rate

\begin{tabular}{lc}
\hline \multicolumn{1}{c}{ Items } & Result \\
\hline Distributed Questionnaires & 150 \\
Returned Questionnaires & 120 \\
Response Rate & $80 \%$ \\
\hline
\end{tabular}




\subsection{Descriptive Analysis}

\subsubsection{Respondents Demographic Profile}

Table 4.2

Respondents Demographic Profile

\begin{tabular}{|c|c|c|}
\hline Age & Frequency & Percentages \\
\hline Below 21 years & 2 & 1.7 \\
\hline 21-30 years & 81 & 67.5 \\
\hline $31-40$ years & 29 & 24.2 \\
\hline $41-50$ years & 7 & 5.8 \\
\hline $51-60$ years & 1 & 0.8 \\
\hline Above 60 years & 0 & 0 \\
\hline Total & 120 & 100.0 \\
\hline Gender & Frequency & Percentages \\
\hline Male & 39 & 32.5 \\
\hline Female & 81 & 67.5 \\
\hline Total & 120 & 100.0 \\
\hline Highest Education Level & Frequency & Percentages \\
\hline Secondary school & 5 & 4.2 \\
\hline Certificate/Diploma or equivalent & 20 & 16.7 \\
\hline Bachelor of Degree's or equivalent & 89 & 74.2 \\
\hline Master Degree or equivalent & 5 & 4.2 \\
\hline Doctoral Degree & 1 & 0.8 \\
\hline Total & 120 & 100.0 \\
\hline Length of Services & Frequency & Percentages \\
\hline Up to 5 years and below & 80 & 66.7 \\
\hline $6-10$ years & 22 & 18.3 \\
\hline $11-15$ years & 13 & 10.8 \\
\hline $16-20$ years & 1 & 0.8 \\
\hline More than 20 years & 4 & 3.3 \\
\hline Total & 120 & 100.0 \\
\hline Monthly Income Level & Frequency & Percentages \\
\hline Below RM2,000.00 & 4 & 3.3 \\
\hline RM2,501.00 - RM 5,000.00 & 80 & 66.7 \\
\hline RM5,001.00 - RM7,500.00 & 23 & 19.2 \\
\hline RM7,501.00 - RM10,000.00 & 10 & 8.3 \\
\hline Above RM10,000.00 & 3 & 2.5 \\
\hline Total & 120 & 100.0 \\
\hline
\end{tabular}


The results of the frequency distributions and percentages are obtained for demographic profile by using Statistical Package for Social Science (SPSS) 23.0. The finding results are shows as above table.

According to Table 4.2 showed that the highest number of respondents are fresh graduate which represents by those in age group 21-30 years old in which $81(67.5 \%)$ out of total 120 respondents. There are 29 (24.2\%) respondents from age group 31-40 years old following by 7 (5.8\%) respondents from age group 41-50 years old and below 21 years old age group represented by 2 respondents or $1.7 \%$ out of $100 \%$. Besides that, there is only 1 respondent $(0.8 \%)$ is from age group 51-60 years old.

In addition, the Table 4.2 showed the largest group of respondents who represent in this study is female (67.5\%) and following by remaining 39 respondents $(32.5 \%)$ come from men staffs.

Out of 120 respondents, there are 89 respondents or $74.2 \%$ who have Bachelor of Degree's or equivalent education level following by Certificate/Diploma or equivalent which represent by 20 respondents $(16.7 \%)$ as per above Table 4.2 . Besides that, there are two education level group have same numbers of respondents which they are from secondary school and Master Degree or equivalent education level for $4.2 \%$ or 5 respondents. Lastly, one respondent is from Doctoral Degree education level who participates in this study.

Moreover, the result of Table 4.2 shown that most of the respondents length of service is up to 5 years and below for $66.7 \%$ or 80 respondents. The employees who are serving for more than 20 years in banking industries have 4 people out of total 120 
respondents. Furthermore, only one respondent have 16-20 years of service experience in banking industries. Apart from that, for years of service 11 to 15 have 13 or $10.8 \%$ respondents in this study and following by $18.3 \%$ of respondents have 6 to 10 years working experience in banking industries.

The range of monthly income level is the indicator of the respondent's life style and spending pattern. The highest numbers of respondents for monthly income level is between the range of RM2,501.00 - RM 5,000.00 for 80 respondents out of total 120 respondents. However, there are 4 respondents for monthly income below RM2,000.00; and 3 respondents for above RM10,000.00. Besides, 23 (19.2\%) respondents monthly income are within the range RM5,001.00 - RM7,500.00. There are 10 respondents or 8.3\% monthly income in range RM7,501.00 - RM10,000.00.

\subsubsection{Descriptive Analysis}

Table 4.3 indicates the descriptive analysis of turnover intention among the bank employees that located nearby Masjid Jamek areas, Kuala Lumpur. This is because the descriptive analysis is use to evaluate the employees' perception towards the employee relations, working environment and conditions, compensation and benefit packages, and career advancement opportunities as well as employees turnover intention. 
Table 4.3

Descriptive Analysis

Turnover Intention

Mean

I will spend my entire career with this organization.

2.56

I intend to leave this organization within a short period of time.

2.75

I have decided to quit this organization.

2.70

I am looking at other jobs now.

2.93

If I do not get promoted soon, I will look for a job elsewhere.

3.18

Total Average Mean

2.82

\begin{tabular}{lc}
\hline Employee Relations & Mean \\
\hline I have good working relationships with my colleagues. & 4.01 \\
I have socialized with my colleagues during breaks at workplace. & 3.91 \\
My colleagues have helped me in performing my tasks. & 4.08 \\
Total Average Mean & 4.00
\end{tabular}

Working Environment and Conditions Mean

My working conditions are up to satisfactory standards.

3.32

All required resources are available to me.

3.23

The working environment is conducive.

3.34

The comfort I am provided at work is high.

3.31

Total Average Mean

3.30

Compensation and Benefit Packages

Mean

I am satisfied with my total income earned.

2.70

I am satisfied with the hourly wage that I receive.

2.58

I am satisfied with the amount of recognition that I receive.

2.72

Total Average Mean

2.67

Career Advancement Opportunities

Mean

Organization developmental efforts have improved my self-awareness, 3.56 competencies, and employability.

I have made sufficient progress to achieve my career goals.

Organization management has provided me with adequate resources needed for my development.

Employee development is perceived in a positive way.

Employee development decisions are made in an unbiased manner.

Total Average Mean 
There are five items that used to measures the employees' perception towards turnover intention. Based on the result of analysis, the higher mean is 3.18 that falls under range 5. The respondents agree to that particular statement that employees will look for other job if they do not get promotion. In the overall, the answer range of respondents are more to agree to say the existing of turnover intention among themselves as the total averages shows 2.82 mean indeed.

Table 4.3 indicates the descriptive analysis of employee relations among the bank employees that located nearby Masjid Jamek areas, Kuala Lumpur. There are three items that used to measures the employees' perception towards employee relations. Based on the result, the higher mean is 4.08 that falls under range 3 and this result shows the respondents agree to that particular statement and follow by mean 4.01 that falls under range 1 and lastly the statement agree by respondents are falls under range 2 with mean 3.91. In the overall, the answer range of respondents are more to agree to say the existing of turnover intention among themselves as the total averages shows 4.00 mean indeed.

Besides that, Table 4.3 also indicates the descriptive analysis of working environment and conditions among the bank employees that located nearby Masjid Jamek areas, Kuala Lumpur. There are four items that used to measures the employees' perception towards working environment and conditions. Based on the result of analysis, the higher mean is 3.34 that fall under range 3 and this result shows the respondents agree to that particular statement. Besides that, the second higher mean is 3.32 that fall under range 1 follow by mean 3.31 that fall under range 4 . The lower mean is 3.23 which fall under range 2 . In the overall, the answer range of respondents are more to 
agree to say the existing of turnover intention among themselves as the total averages shows 3.30 mean indeed.

Furthermore, Table 4.3 also indicates the descriptive analysis of compensation and benefit packages among the bank employees that located nearby Masjid Jamek areas, Kuala Lumpur. There are three items that used to measures the employees' perception towards compensation and benefit packages. Based on the result of analysis, the higher mean is 2.72 that fall under range 3 and this result shows the respondents agree to that particular statement. In the overall, the answer range of respondents are more to agree to say the existing of turnover intention among themselves as the total averages shows 2.67 mean indeed.

Moreover, Table 4.3 are indicates the descriptive analysis of career advancement opportunities among the bank employees that located nearby Masjid Jamek areas, Kuala Lumpur. There are five items that used to measures the employees' perception towards career advancement opportunities. Based on the result of analysis, the higher mean is 3.56 that shows the respondents agree to that particular statement. In the overall, the answer range of respondents are more to agree to say the existing of turnover intention among themselves as the total averages shows 3.40 mean indeed. 


\subsection{Pearson Correlation Analysis}

The purpose of Pearson's correlation analysis is used to determine the relationship between dependent variable and independent variables for this study. Table 4.4 shows the result of correlation analysis that carried out for the dependent variable and independent variables.

Table 4.4

Pearson's Correlation Analysis Results

\begin{tabular}{cccccc}
\hline & TI & ER & WEC & CBP & CAO \\
\hline TI & 1 & & & & \\
ER & -0.042 & 1 & & & \\
WEC & -0.461 & 0.296 & 1 & & \\
CBP & -0.432 & 0.051 & 0.300 & 1 & \\
CAO & -0.306 & 0.161 & 0.512 & 0.248 & 1 \\
\hline
\end{tabular}

Note: TI=Turnover Intention, ER=Employee Relations,

WEC $=$ Working Environment $\&$ Conditions, $\mathrm{CBP}=$ Compensation \& Benefit Packages, $\mathrm{CAO}=$ Career Advancement Opportunities

Based on Table 4.4 it discusses the relationship between dependent variable and independent variables of the turnover intention among bank employees in Kuala Lumpur, Malaysia. According to the above table shows that the relationship of each independent variable with employees turnover intention is $r=-0.042$ for employee relations, $r=-0.461$ for working environment $\&$ conditions, $r=-0.432$ for compensation $\&$ benefit packages, and $\mathrm{r}=-0.306$ for career advancement opportunities. The relationship between the dependent variable and four of the independent variables shows negative relationship. The negative relationship shows that the level of satisfaction of employees towards independent variable that include employee relations, working environment and conditions, compensation and benefit packages, career advancement opportunities is 
decrease, the turnover intention among the employees in banking industry will increase. From the correlation value suggested by Davis (1971), the result indicate that the strength of relationship between turnover intention and employee relations is weak ( $\mathrm{r}=-$ 0.042). However, the result are indicate that the strength of relationship between turnover intention and working environment \& conditions $(\mathrm{r}=-0.461)$, compensation \& benefit packages ( $r=-0.432)$, as well as career advancement opportunities $(r=-0.306)$ is moderate.

\subsection{Multiple Regression Analysis}

Table 4.5

Model Summary

\begin{tabular}{c|ccc}
\hline $\mathbf{R}$ & R Square & $\begin{array}{c}\text { Adjusted R } \\
\text { Square }\end{array}$ & $\begin{array}{c}\text { Std. Error of the } \\
\text { Estimate }\end{array}$ \\
\hline $.563^{\mathrm{a}}$ & .317 & .294 & .56521 \\
\hline
\end{tabular}

Predictors: (Constant), Employee Relations, Working Environment \& Conditions, Compensation \& Benefit Packages, Career Advancement Opportunities

According to table 4.5 , the $\mathrm{R}$ square shows result of 0.317 (31.7\%). In other words, the result described that the four independent variables of this research includes employee relations, working environment \& conditions, compensation \& benefit packages, career advancement opportunities are the main factors contributing towards bank employee's turnover intention in Kuala Lumpur, Malaysia. It also refers that 31.7\% of the variance had been founded and explained by using this four independent variables. Meanwhile, there is remaining $68.3 \%$ of employee turnover intention in banking industry is influence by other factors. 
Table 4.6

Multiple Regression Analysis Results

\begin{tabular}{|c|c|c|c|c|c|}
\hline & B & $\begin{array}{c}\text { Std. } \\
\text { Error }\end{array}$ & Beta & $t$ & Sig. \\
\hline (Constant) & 4.341 & 0.419 & & 10.354 & 0.000 \\
\hline Employee Relations & 0.097 & 0.086 & 0.090 & 1.120 & 0.265 \\
\hline $\begin{array}{l}\text { Working Environment } \\
\& \text { Conditions }\end{array}$ & -0.328 & 0.085 & -0.366 & -3.856 & 0.000 \\
\hline $\begin{array}{l}\text { Compensation \& } \\
\text { Benefit Packages }\end{array}$ & -0.231 & 0.060 & -0.313 & -3.852 & 0.000 \\
\hline $\begin{array}{l}\text { Career Advancement } \\
\text { Opportunities }\end{array}$ & -0.062 & 0.100 & -0.055 & -0.613 & 0.541 \\
\hline
\end{tabular}

a. Dependent Variable: Turnover Intention

The multiple regression analysis is used to study the significant relationship between dependent variable and independent variables. If $p$-value $=p<0.05$, shows that there is a significant relationship between dependent variable and independent variables. Vice versa, if $p$-value $=p<0.05$ meant that there is no significant relationship between dependent variable and independent variables. Based on the table 4.6 shown that, there are two independent variables have significant relationship with dependent variable turnover intention, which are working environment and conditions, and compensation and benefit packages. 


\subsection{Hypotheses Testing}

H1: There is a negative and significant relationship between employee relations and turnover intention.

Table 4.6 shows that there is no significant relationship between employee relations and turnover intention. This is because the significant value is $\beta=0.090$, $\mathrm{p}=0.265 ;(\mathrm{p}>0.05)$ and the $\mathrm{t}-\mathrm{value}=1.120$. Therefore, the hypothesis for this relationship is rejected.

H2: There is a negative and significant relationship between working environment and conditions and turnover intention.

Table 4.6 shows that there is a significant relationship between working environment \& conditions and turnover intention as indicated by the t-value is -3.856 and the significant value is shows $\beta=-0.366, p=0.000 ;(p<0.05)$. Hence, the hypothesis for this relationship is accepted.

H3: There is a negative and significant relationship between compensation \& benefit packages and turnover intention.

Table 4.6 shows that there is a significant relationship between compensation $\&$ benefit packages and turnover intention. Therefore, the hypothesis for this relationship is accepted as the t-value is -3.852 and the significant value shows that $\beta=-0.313$, $\mathrm{p}=0.000 ;(\mathrm{p}<0.05)$. 
H4: There is a negative and significant relationship between career advancement opportunities and turnover intention.

Table 4.6 shows that there is no significant relationship between career advancement opportunities and turnover intention as indicated by the $\mathrm{t}$-value $=-0.613$ and the significant value is shows $\beta=-0.055, \mathrm{p}=0.541 ;(\mathrm{p}>0.05)$. Therefore, the hypothesis for this relationship is rejected.

Table 4.7

Summary of Hypotheses Testing

\section{Hypotheses}

Result

H1: There is a negative and significant relationship between employee relations and turnover intention.

$\mathrm{H} 2$ : There is a negative and significant relationship between working environment $\&$ conditions and turnover intention.

H3: There is a negative and significant relationship between compensation \& benefit packages and turnover intention.

H4: There is a negative and significant relationship between Rejected career advancement opportunities and turnover intention. 


\subsection{Chapter Summary}

This chapter discusses the results of the descriptive and inferential statistical analyses on the data collected through the questionnaires distribution. The findings show that there are negative correlation between four independent variables that includes employee relations, working environment and conditions, compensation and benefit packages, career advancement opportunities with dependent variable turnover intention. The strength of relationship between turnover intention and employee relations is weak. Moreover, the finding shows that there are three variables (working environment \& conditions, compensation \& benefit packages, and career advancement opportunities) are moderately correlated to the turnover intention among the bank employees in Kuala Lumpur, Malaysia. 


\section{CHAPTER FIVE \\ DISCUSSION AND CONCLUSION}

\subsection{Introduction}

This final chapter summarizes and discusses the findings of the analysis in previous chapter. Therefore, this chapter begins the discussion of research objectives and limitation of the study followed by suggestions for future research. Lastly, the chapter ends with the conclusion of the study.

\subsection{Discussion of Findings}

There are totally four objectives that mentioned in chapter one for this study. Hence, the discussions of the objectives result are as below.

\subsubsection{The relationship between employee relations and turnover intention}

The first objective of this research is to examine the relationship between employee relations and turnover intention. According to multiple regression analysis finding shown in Table 4.6, there is no significant relationship between employee relations and turnover intention with the reading of significant value is $\mathrm{p}=0.265(\mathrm{p}>0.05)$. The employee relations are crucial in order to maintaining a healthy working relationship among the management team and employees. According to Choi et al., (2012) stated that good employee relations are able to contribute and sustain employees' productivity and enhance service quality stability as well as to meet the organizational goals. Nowadays, everyone is concern about the employee relations especially when 
there is growing attention to employee rights as well as can increase the employee's job satisfaction (Lee, Huang \& Zhao, 2012). Generally, poor relationship among the employees will increase the turnover intention of employees. However, this study shows that there is no significant relationship between employee relations and turnover relations in banking industry at Kuala Lumpur, Malaysia. Therefore, a research result is found no consistent between employee relations and turnover intention (Lee et al., 2012). Hence, the employee turnover intention is not affected by the employee relations.

\subsubsection{The relationship between working environment and conditions and turnover intention.}

The second objective of this research is to examine the relationship between working environment and conditions and turnover intention. According to multiple regression analysis finding shown in Table 4.6 , there is a significant relationship between working environment $\&$ conditions and turnover intentions with the reading of significant value $\mathrm{p}=0.000(\mathrm{p}<0.05)$. The conducive working environment and conditions such as proper lighting, clean and clear environment, staff rest room, and so on will increase the employees' service quality and corporate image (Lee et al., 2012). This is because that the working environment and conditions in banking industry is stressful due to long working hours, dealing with more complicated tasks, as well as irregular vacation days (Choi et al., 2012). Moreover, the poor banking system and software are unable to support for daily operation such as Automated Teller Machine (ATM) and other banking system being interrupted during operation hours. This negative and significant relationship had been supported by Kanwal and Tariq (2016) that the 
working environment and conditions is found significant with employee turnover intention. In addition, Sattar and Ahmad (2014) studies shows that work environment and conditions have large impact on employee turnover intention and it is significant with this study. Accordingly, the research result for this objective is proven to be true with past finding support.

\subsubsection{The relationship between compensation and benefit packages and turnover intention.}

The third objective of this research is to examine the relationship between compensation and benefit packages and turnover intention. According to multiple regression analysis finding shown in Table 4.6, there is a significant relationship between compensation \& benefit packages and turnover intention with the reading of $p=0.000(p<0.05)$. According to Nair, Cheik, and Lim (2016) defined the compensation as the total rewards to employees in return for their services with the purpose to attracting, retaining and motivation employees. Usually, the compensation and benefit packages includes all form of pay, rewards, bonuses, commission, leaves, flexi work hours, medical insurance, and others (Choi, et al., 2012). Besides that, Emiroglu, Tanriverdi \& Akova (2015) mentioned that the employees will leave the organization once they founded that there is a mismatch between the job and reward, vice versa, the employees are motivate to stay and work harder for more rewards (Kanwal \& Tariq, 2016). The result of this study is consistent with Emiroglu, Akova, and Tanriverdi (2015) as they found out the compensation and benefit packages is significant with employee turnover intention because the employees have relatively lower salaries groups have 
higher turnover intention than people which have higher salaries. Moreover, Hassan (2014) stated the compensations and benefit packages is negatively and significant effect on employee turnover intention. Hence, it is proven that significant relationship between compensation and benefit packages and employee turnover intention is true with support from past studies evidences.

\subsubsection{The relationship between career advancement opportunities and turnover intention.}

The last objective of this research is to examine the relationship between career advancement opportunities and turnover intention. According to multiple regression analysis finding shown in Table 4.6, there is no significant relationship between career advancement opportunities and turnover intentions as indicated by the significant value $\mathrm{p}=0.541(\mathrm{p}>0.05)$. The career advancement opportunity is enable the employees to take their responsibility for own career planning and progress (Choi, et al., 2012). Apart from that, career advancement opportunities is also the way of organization provide the opportunities for employees to grow in order to support the intentions of the employees to stay in the organization, vice versa, the barrier on career advancement opportunities will increase the turnover intentions among the employees (Kanwal \& Tariq, 2016). According to Sattar \& Ahmed (2014) studies shows that the career advancement opportunities is an impact on employee turnover intention, in which, the result is no consistent with this research. Similarly, based on the result studies of Kanwal and Tariq (2016) shows that the career advancement opportunities is significant with turnover intention, and the result is also no consistent with this study as well. 


\subsection{Implications of the Research}

Generally, the issue of employee turnover intention is common happening around worldwide. Therefore, the purpose of this research is to identify the factors that contribute to the employee turnover intentions, especially for banking industry in Kuala Lumpur, Malaysia. The employees are main key in all the organizations, either in private or public sector. The high number of employees voluntary turnover intentions is significant their dissatisfaction on their current jobs or workplace.

From the research result shows that the factor of working environment and conditions as well as the factor of compensation and benefit packages are significant with turnover intention. Practically, the finding is enabling the management team and human resource department to take the necessary actions in order to reduce the number of employee turnover intention in their respective organizations. For instance, the supervisor or manager should giving more autonomy and trust to the employees. As a result, the employees may keen to take up more responsibilities and new challenges on their jobs. This is because the employees are more likely to develop higher engagement level with the organization and subsequently to reduce the turnover intention if the organizations are able to proving a workplace that suits the needs of each generation such as Gen-Y and others. Besides that, most of the fresh graduate will not tend to stay for longer period with same position as they will looking for better offer of compensation and benefit packages from the competitor organizations.

Theoretically, this research has provided useful information to future researcher who are conduct the research that related to this subject. This is because the results of the research are assisting the future researcher to understand the factors that causes high 
number of employee turnover intention in banking industry such as the working environment and conditions, employee relations, compensation and benefit packages, and career advancement opportunities. As we know that those factors will causes high number of employee turnover intention. Consequences of the employee's turnover intention might affect the organization reputation and operation as well as the capability to meet their mission and vision.

\subsection{Limitation of the Study}

During the process of research being carried out, there are few limitations of the study. The first challenge was the researcher unable to get the permission from the selected banking industry. The researcher have emailed to the selected banking industry person-in-charge to get the permission to collect secondary data from their employees and to get the information on actual number of employees in their respective office. Unfortunately, there was no responding from all of them.

Apart from that, the researcher distributed the questionnaires to the target respondents during lunch hours and after working hours. It is a challenge for researcher on searching for voluntary respondents to participate in this survey. This is because the subject of turnover intention among the bank employees is a sensitive issue. The respondents might be worry if their respond may found out by their employers and would prejudice against them in workplace. Besides, some of the respondents are refusing to give cooperation to participate in this survey because they were rushing for their lunchtime or going back home to avoid traffic jam. Therefore, this circumstance 
will lead to slow progress for the researcher to collect the data from the target respondents.

\subsection{Suggestions for Future Research}

In overall, the purpose of this research is to study the determinants of turnover intention among bank employees in Kuala Lumpur, Malaysia. Therefore, the research findings is use to identify the relationship between four independent variables which include the employee relations, working environment and conditions, compensation and benefit packages, and career advancement opportunities, with dependent variable, turnover intention. According to the multiple regressions analysis result shows that the four independent variables are contributing towards bank employee's turnover intention in Kuala Lumpur, Malaysia is only $31.7 \%$. The remaining of the $68.3 \%$ bank employee's turnover intention is cause by other factors such as alternative employment opportunities, authentic leadership, and others. Queiri et al., (2015) have been identified the factor of alternative employment opportunities is one of the causes employees turnover in their research. Meanwhile, Azanza et al., (2015) research also stated that authentic leadership is the causes of employees leaving organization. Hence, there are few suggestions for future researcher that might be helps for their research.

The first suggestion is the researcher may explore more related external and internal factors that cause the bank employees turnover intention. For example, the external factors are including economic development level, job opportunities, labor market condition, changes of politics, changes in technology, and so on. Generally, the external factors might lead to bank employee's turnover intention because the high 
economic development level will create more job opportunities, and the bank employees will starts to looking for better offer in order to increase their lifestyle. Besides that, the changes in technology also will lead to bank employee's turnover intention especially for senior employees. This is because they are unable to control and handle the technology for their daily operations, thus, they might be leave the organization and looking for other job that suit for them. Furthermore, the internal factors such as workforce diversity, organization culture, organization procedures, organization structure, personal factors, and others will also lead to turnover intention among the bank employees. As we know that different organization has different culture, procedures, as well as culture. Therefore, the employees will find the job according to their characteristics and personal factors.

Another suggestion for future researcher is they should focus the banking industry in whole Malaysia instead of Kuala Lumpur. This is because by conducting the research in rural and urban areas that include the banking industry sector, either in private and government in order to get the interesting information. Apart from that, the researcher should also collect the data from all level position of employee as well as involve local and international banks in order to get accurate result without neglecting any parties for future research. 


\subsection{Conclusion}

As a conclusion, this research finding shows that all the independent variables which are employee relations, working environment and conditions, compensation and benefit packages, as well as career advancement opportunities have negative relationship with turnover intention. In other words, if the independent variables level decreased, the dependent variable level is increased, and vice versa. In addition, there are two variables such as working environment and conditions, and, compensation and benefit packages have significant relationship with turnover intention. However, there are another two variables such as employee relations and career advancement opportunities do not have any significant relationship with turnover intention. The high number of turnover intention among the bank employees will create many problems to the organizations. Hence, the organization and the management team should find the solutions towards this issue in order to ensure the stability of the banking institutions and the stability of economy as well. 


\section{REFERENCES}

Adler, H. \& Ghiselli, R. (2015). The importance of compensation and benefits on university students' perception of organizations as potential employers. Journal of Management and Strategy, 6(1), 1-9.

Afif, S. H., Sanjay, K. S. \& Matloub, H. (2015). Correlates of employee turnover intentions in oil and gas industry in the UAE. International Journal of Organizational Analysis, 23(3), 493-504.

Alipour, M., Salehi, M. \& Shahnavaz, A. (2009). A study of on the job training effectiveness: empirical evidence of Iran. International Journal of Business and Management, 4(11), 63-68.

Azanza, G., Moriano, J. A., Molero, F. \& Mangin, J. P. L. (2015). The Effects of authentic leadership on turnover intention. Leadership \& Organization Development Journal, 36(8), 955-971.

Bigliardi, B., Petroni, A. \& Dormio, A. I. (2005). Organizational socialization, career aspirations and turnover intentions among design engineers. Leadership \& Organization Development Journal, 26(6), 424-441.

Blau, P. M. (1964). Exchange and power in social life. New York: John Wiley. 
Blom, V. \& Aronsson, G. (2010). Work conditions for workers with good long-term health. International Journal of Workplace Health Management, 3(2), 160-172.

Boyer, K. K. (1996). An assessment of managerial commitment to lean production. International Journal of Operation \& Production Management, 16(9), 48-59.

Bryman, A. \& Bell, E. (2011). Business research methods (3rd ed.). New York:

Oxford University Press. Chen, Y., Friedman, R. \& Simons, T. (2014). The gendered trickle-down effect. Career Development International, 19(7), 836-856.

Chepkwony, C. C. (2014). The relationship between rewards systems and job satisfaction: a case study at teachers service commission-Kenya. European Journal of Business and Social Sciences, 3(1), 59-70.

Chew, I. \& Goh, M. (1997). Some future directions of human resource practices in Singapore. Career Development International, 2(5), 238-244.

Ching, S. L. \& Kee, D. M. H. (2012). Work values-career commitment relationship of generation Y teachers in Malaysia 2012. International Conference on Economics Marketing and Management, Vol.28, 242-246. 
Choi, S., Cheong, Kiju. \& Feinberg, R. A. (2012). Moderating effects of supervisor support, monetary rewards, and career paths on the relationship between job burnout and turnover intentions in the context of call centers. Managing Service Quality: An International Journal, 22(5), 492-516.

Choi, S. L., Ajagbe, M. A. \& Tan, O. K. (2013). Addressing the issues on employees' turnover intention in the perspective of HRM practices in SME. Procedia - Social and Behavioral Sciences 129, 99-104.

Choi, S. L. \& Panniruky, P. (2014). Examining the impact of human resource management practices on employees' turnover intention. International Journal of Business and Society, 15(1), 111-126.

Choi, S. L., \& Panniruky, P., \& Ajagbe, M. A. (2012). The impact of human resource management practices on employees' turnover intention: a conceptual model. Interdisciplinary Journal of Contemporary Research in Business, 4(2), 629-641.

Cohen, G., Blake, R. S., \& Goodman, D. (2015). Does turnover intention matter? Evaluating the usefulness of turnover intention rate as a predictor of actual turnover rate. Review of Public Personnel Administration, 1-24.

Cooper, D. R., \& Schindler, P. S. (2011). Business research methods (11st ed.). New York: McGraw-Hill/Irwin. 
Cropanzano, R. \& Mitchell, M. S. (2005). Social exchange theory: an interdisciplinary review. Journal of Management, 31(6), 874-900.

Davis, J. A. (1971). Elementary survey. Englewood Cliffs, New Jersey: Prentice Hall.

Department of Statistics Malaysia (2016). Statistical handbook.

Retrieved on Mar 18, 2017, from

file://C:/Users/user/Downloads/BUKU\%20MAKLUMAT\%

20PERANGKAAN\%20MALAYSIA\%202016\%2015.12.2016.pdf

Dysvik, A. \& Kuvaas, B. (2010). Exploring the relative and combined influence of mastery-approach goals and work intrinsic motivation on employee turnover intention. Personnel Review, 39(5), 622-638.

Emerson, R. M. (1976). Social exchange theory. Annual Review of Sociology, Vol.2, $335-362$.

Emiroglu, B. D., Tanriverdi, H. \& Akova, O. (2015). The relationship between turnover intention and demographic factors in hotel businesses: a study at five star hotels in Istanbul. Procedia - Social and Behavioral Sciences, 207, 385-397.

Gill, A. S. (2008). The role of trust in employee-manager relationship. International Journal of Contemporary Hospitality Management, 20(1), 98-103. 
Harter, J. K., Schmidt, F. L. \& Hayes, T. L. (2002). Business-unit-level relationship between employee satisfaction, employee engagement, and business outcomes: a meta- analysis. Journal of Applied Psychology, 87(2), 268-279.

Hassan, R. (2014). Factors influencing turnover intention among technical employees in information technology organization: a case of XYZ (M) Sdn Bhd. International Journal of Arts and Commerce, 3(9), 120-137.

Hofhuis, J., van der Zee, K. I. \& Otten, S. (2014). Comparing antecedents of voluntary job turnover among majority and minority employees. Equality, Diversity and Inclusion: An International Journal. 33(8), 735-749.

Huang, W. R. \& Su, C.H. (2016). The mediating role of job satisfaction in the relationship between job training satisfaction and turnover intentions. Industrial and Commercial Training, 48(1), 42-52.

Hussain, I. A., Yunus, N., Ishak, N. A. \& Daud, N. (2013). The influence of intention to leave towards employee engagement among young bankers in Malaysia. International Journal of Business and Management, 8(14), 89-97.

Irfann Ismail, M. \& Tan, T. H. (2011). Identifying work-related stress among employees in the Malaysian financial sector. World Journal of Management. 3(2), 229-243. 
Javed, M., Balouch, R. \& Hassan, F. (2014). Determinants of job satisfaction and its impact on employee performance and turnover intentions. International Journal of Learning and Development, 4(2),120-140.

Jha, S. (2009). Determinants of employee turnover intentions: a review.

Management Today, 9(2), 26-33.

JobStreet.com (2018). Malaysia ranks the $4^{\text {th }}$ in recent Employee Job Happiness Index 2017. Retrieved on Mar 31, 2018, from https://www.jobstreet.com.my/career-resources/malaysia-ranks-4th-recentemployee-job-happiness-index-2017-jobstreet-com/\#.WsDoli5ubIU

Kanwal, B. \& Tariq, A. (2016). Organizational environment, job satisfaction and career growth opportunities: a link to employee's turnover intentions in University of Sargodha, Pakistan. Journal of Resources Development and Management, $20(1), 8-14$.

Kaur, G. (2015). Perception of bank employees' towards working environment of selected Indian universal banks. International Journal of Bank Marketing, $33(1), 58-77$. 
Keni., Muthuveloo, R., Teoh. A. P. \& Rubiah Rahman, A. (2013). Turnover intention trend among commercial banks in Penang, Malaysia. International Conference on Entrepreneurship and Business Management (ICEBM), 10-15.

Khan, A. H. \& Aleem, M. (2014). Impact of job satisfaction on employee turnover: an empirical study of autonomous medical institutions of Pakistan. Journal of International Studies, 7(1), 122-132.

Khatri, N. (1999). Emerging issues in strategic HRM in Singapore. International Journal of Manpower, 20(8), 516-529.

Khatri, N., Budhwar, P. \& Chong, T. F. (1999), Employee turnover: bad attitude or poor management? Nanyang Business School, Nanyang Technological University, Singapore

Kim, S., Tam, L., Kim, J. N. \& Rhee, Y. (2017). Determinants of employee turnover intention: understanding the roles of organizational justice, supervisory justice, authoritarian organizational culture and organization-employee relationship quality. Corporate Communications: An International Journal, 22(3), 308-328.

Koslowsky, M., Weisberg, J., Yaniv, E. \& Speiser, I. Z. (2012). Ease of movement and sector affiliation as moderators of the organizational and career commitment. International Journal of Manpower, 33(7), 822-839. 
Kossivi, B., Xu, M. \& Kalgora, B. (2016). Study on determining factors of employee retention. Open Journal of Social Sciences, 4, 261-268.

Labour Force Statistics Malaysia (2016). Unemployment rate in Malaysia from 2010-2015. Retrieved on Sep 23, 2016, from https://www.statistics.gov.my/index.php?r=column/cthemeByCat\&cat=155\&bul_ id=OWlxdEVoYlJCS0hUZzJyRUcvZEYxZz09\&menu_id=L0pheU43NWJwRW VSZklWdzQ4TlhUUT09

Latif, K., Shahid, M. N. \& Sohail, N. (2011). Job satisfaction among public and private college teachers of district Faisalabad, Pakistan: a comparative analysis. Interdisciplinary Journal of Contemporary Research in Business, 3(8), 235-242.

Leblebici, D. (2012). Impact of workplace quality on employee's productivity: case study of a bank in Turkey. Journal of Business, Economics \& Finance, 1(1), 38-49.

Lee, C. C., Huang, S. H, \& Zhao, C. Y. (2012). A study of factors affecting turnover intention of hotel employees. Asian Economic and Financial Review, 2(7), 866-876.

Lee, C. S., Kee, D. M. H., \& Tan, C. L. (2012). Work values of generation Y preservice teachers in Malaysia. Procedia - Social and Behavioral Sciences 65, 704-710. 
Lee, H. W. \& Liu, C. H. (2007). An examination of factors affecting repatriates' turnover intentions. International Journal of Manpower, 28(2), 122-134.

Lee, T. R., Chen, S. Y., Wang, S. H. \& Dadura, A. (2010). The relationship between spiritual management and determinants of turnover intention. European Business Review, 22(1), 102-116.

Martocchio, J. J. (2015). Strategic compensation: a human resources management aproach $\left(8^{\text {th }}\right.$ ed.). England: Pearson Education Limited

McLeod, S. (2016). Maslow's hierarchy of needs. Retrieved on Oct 01, 2016, from: http://www.simplypsychology.org/maslow.html

Menefee, J. A. \& Murphy, R. O. (2004). Rewarding and retaining the best: compensation strategies for top performers. Benefits Quarterly, 20(3), 13-20.

MOHR, Department of Labour of Peninsular Malaysia (2016). Statistik pekerjaan dan perburuhan. Retrieved on Sep 23, 2016, from http://myhos.mohr.gov.my/ebook/istatistik3_2016/index.html\#p=28

Nair, S., Cheik, A. N. \& Lim, Y. M. (2016). Internal push factors and external pull factors and their relationships with lecturers' turnover intention. International Journal of Business and Management, 11(12), 110-126. 
Ntalianis, F., Dyer, L., \& Vandenberghe, C. (2015). Owner-employee relations in small firms. Journal of Managerial Psychology, 30(7), 832-846.

Osibanjo, A. O., Adeniji, A. A., Falola, H, O. \& Heirsmac, P. T. (2014). Compensation packages: a strategic tool for employees' performance and retention. Leonardo Journal of Sciences, Issues 25, 65-84.

Osibanjo, A. O., Oyewunmi, A. E. \& Ojo, S. I. (2014). Career development as a determinants of organizational growth: modeling the relationship between these constructs in the Nigerian banking industry. American International Journal of Social Science, 3(7), 67-75.

Pasamar, S. \& Valle, C. R. (2013). Work-life balance under challenging financial and economic conditions. International Journal of Manpower, 34(8), 961-974.

Qasim, T., Javed, U. \& Shafi, M. S. (2014). Impact of stressors on turnover intention: examining the role of employee well-being. International Journal of Science, Behavioral, Educational, Economic, Business and Industrial Engineering, 8(1), 176-184.

Queiri, A., Wan Fadzilah Yusoff, W. \& Dwaikat, N. (2015). Explaining generation-Y employees' turnover in Malaysian context. Asian Social Science, 11(10), 126-138. 
Rahim, A. \& Cosby, D. M. (2016). A model of workplace incivility, job burnout, turnover intentions, and job performance. Journal of Management Development, $35(10), 1255-1265$.

Rahman, M. M. \& Iqbal, M. F. (2013). A comprehensive relationship between job satisfaction and turnover intention of private commercial bank employees' in Bangladesh. International Journal of Science and Research, 2(6), 17-23.

Rahman, W. \& Nas, Z. (2013). Employee development and turnover intention: theory validation. European Journal of Training and Development, 37(6), 564-579.

Ramzan, M., Hafiz Zubair, M. K., Ali, G. \& Arslan, M. (2014). Impact of compensation on employee performance (empirical evidence from banking sector of Pakistan). International Journal of Business and Social Science, 5(2), 302-309.

Rizal, M., Syafie Idrus, M., Djumahir. \& Mintarti, R., (2014). Effect of compensation on motivation, organizational commitment and employee performance (studies at local revenue management in Kendari City). International Journal of Business and Management Invention, 3(2), 64-79. 
Saeed, I., Waseem, M. \& Sikander, S. (2014). The relationship of turnover intention with job satisfaction, job performance, leader member exchange, emotional intelligence and organizational commitment. International Journal of Learning \& Development, 4(2), 242-256.

Sajjad, N., Amina, S., Wang, Q., Nadia, N. \& Quang, D. T. (2016). Influence of organizational rewards on organizational commitment and turnover intentions. Employee Relations, 38(4), 596-619.

Samgnanakkan, S. (2016). Mediating role of organizational commitment on HR practices and turnover intention among ICT professionals. Journal of Management Research, 10(1), 39-61.

Sattar, S. \& Ahmed, S, (2014). Factors effecting employee turnover in banking sector. Developing Country Studies, 4(3), 110-115.

Settoon, R., Bennett, N. \& Liden, R. (1996). Social exchange in organizations: perceived organizational support, leader-member exchange, and employee reciprocity. Journal of Applied Psychology, 81(3), 219-227.

Shah, N. H. \& Jumani, N. B. (2015). Relationship of job satisfaction and turnover intention of private secondary school teachers. Mediterranean Journal of Social Science, 6(4), 313-323. 
Shukla, S. \& Sinha, A. (2013). Employee turnover in banking sector: empirical evidence. Journal of Humanities and Social Science, 11(5), 57-61.

Singh, S. (2016, March 9). Liow: higher minimum wage decreses dependance on foreign workers. The Star Online. Retrieved on Oct 08, 2016, from: http://www.thestar.com.my/News/Nation/2015/10/25/Liow-higher-minimumwage-fewer-foreign-workers/

Slatten, T., Svensson, G. \& Svaeri, S. (2011). Service quality and turnover intentions as perceived by employees. Personnel Review, 40(2), 205-221.

Tansel, A., \& Gazioglu, S. (2014). Management-employee relations, firm size and job satisfaction. International Journal of Manpower, 35(8), 1260-1275.

The Star Online (2015). Malaysian banks reducing staff.

Retrieved on Sep 25, 2016, from http://www.thestar.com.my/business/business-news/2015/09/17/banksrightsizing-staff/

The Sun Daily Online. (2016). Aon best employers - Malaysia 2016. Retrieved on Oct 05, 2016, from: http://www.thesundaily.my/news/1950522 
The Sun Daily Online. (2016). 31,476 employees laid off between January and

September. Retrieved on Mar 15, 2017, from:

http://www.thesundaily.my/news/2046172

The Sun Daily Online. (2018). Wages too low, says Bank Negara.

Retrieved on Mar 31, 2018, from:

https://www.thestar.com.my/business/business-news/2018/03/31/wages-too-lowsays-bank-negara/

Thomas, K. \& Parveen, K. (2012). Changing work environments and employee wellbeing: an introduction. International Journal of Manpower, 33(7), 729-737.

Wang, E. S. T. (2014). The effects of relationship bonds on emotional exhaustion and turnover intentions in frontline employees. Journal of Services Marketing, 28(4), 319-330.

Wikhamn, W. \& Hall, A. T. (2012). Social exchange in a Swedish work environment. International Journal of Business and Social Science, 3(23), 56-64.

Wills Towers Watson (2013). Higher turnover rate in Malaysia financial services industry, Towers Watson survey finds. Retrieved on Sep 25, 2016, from https://www.towerswatson.com/en/Press/2013/10/Higher-turnover-rate-inMalaysian-Financial-Services-industry 
Xie, B., Xin, X., \& Bai, G. (2016). Hierarchical plateau and turnover intention of employees at the career establishment stage. Career Development International, 21(5), 511-533.

Yaseen, A. (2013). Effect of compensation factors on employee satisfaction: a study of doctor's dissatisfaction in Punjab. International Journal of Human Resources Studies, 3(1), 142-157.

Zhou, J., Qian, X., Henan, Q., \& Lei, X. (2009). Total reward strategic: a human resources management strategy going with the trend of the times. International Journal of Business and Management, 4(11), 177-183.

Zikmund, W. K., Babin, B. J., Carr, J. C., \& Griffin, M. (2013). Business research methods (9th ed.). Canada: Cengage Learning. 
APPENDICES

Universiti Utara Malaysia 


\section{Appendix 1: Sample of Questionnaire}

\section{UNIVERSITI UTARA MALAYSIA}

Dear Respondents,

I am Master of Human Resource Management student of Universiti Utara Malaysia and conducting a survey entitled: The Determinants of Turnover Intention among Bank Employees in Kuala Lumpur, Malaysia that specifically within the banking industry to fulfill the Master's requirement of the university.

I understand recognize that your time is valuable and many demands are made upon it by your heavy workload. However, your participation in this survey, which will require only about 10-15 minutes of your time, is vital to the success of this study.

All information provided in this questionnaire will be confidential for the present study purposes. No information pertaining to individuals will be divulged to any third person or organization. In sum, the information obtained in this study will be used purely for academic purposes only.

Should you have any queries regarding this research please do not hesitate to contact me at yeo chiu@oyagsb.uum.edu.my or call me at 014-9413253. Thank you very much for your cooperation in responding to the questionnaire. Your participation in this study is greatly appreciated.

Sincerely,

\section{YEO CHIU HOON}

MSc of Human Resource Management Student 


\section{Section A - Demographic Profile}

Please tick $(X)$ in the appropriate box or fill in the blank, where appropriate.

1. Your age

\begin{tabular}{|l|l|}
\hline & Below 21 years \\
\hline & $21-30$ years \\
\hline & $31-40$ years \\
\hline & $41-50$ years \\
\hline & $51-60$ years \\
\hline & Above 60 years \\
\hline
\end{tabular}

2. Your gender

\begin{tabular}{|l|l|}
\hline & Male \\
\hline & Female \\
\hline
\end{tabular}

3. Highest education level

\begin{tabular}{|l|l|}
\hline & Secondary school \\
\hline & Certificate/Diploma or equivalent \\
\hline & Bachelor of Degree's or equivalent \\
\hline & Master Degree or equivalent \\
\hline & Doctoral Degree \\
\hline
\end{tabular}

4. Length of Services

\begin{tabular}{|l|l|}
\hline & Up to 5 years and below \\
\hline & $6-10$ years \\
\hline & $11-15$ years \\
\hline & $16-20$ years \\
\hline & More than 20 years \\
\hline
\end{tabular}

5. Monthly Income level

\begin{tabular}{|l|l|}
\hline & Below RM2,000.00 \\
\hline & RM2,501.00 - RM 5,000.00 \\
\hline & RM5,001.00 - RM7,500.00 \\
\hline & RM7,501.00 - RM10,000.00 \\
\hline & Above RM10,000.00 \\
\hline
\end{tabular}




\section{Section B - Turnover Intention}

The following statement is your opinion regarding turnover intention. Please circle an appropriate answer to indicate to what degree you agree or disagree for each statement.

\begin{tabular}{|c|l|c|c|c|c|c|}
\hline No. & Turnover Intention & $\begin{array}{l}\text { Strongly } \\
\text { Disagree }\end{array}$ & Disagree & Neutral & Agree & $\begin{array}{c}\text { Strongly } \\
\text { Agree }\end{array}$ \\
\hline 1 & $\begin{array}{l}\text { I will spend my entire } \\
\text { career with this } \\
\text { organization. }\end{array}$ & 1 & 2 & 3 & 4 & 5 \\
\hline 2 & $\begin{array}{l}\text { I intend to leave this } \\
\text { organization within a } \\
\text { short period of time. }\end{array}$ & 1 & 2 & 3 & 4 & 5 \\
\hline 3 & $\begin{array}{l}\text { I have decided to quit } \\
\text { this organization. }\end{array}$ & 1 & 2 & 3 & 4 & 5 \\
\hline 4 & $\begin{array}{l}\text { I am looking at other } \\
\text { jobs now. }\end{array}$ & 1 & 2 & 3 & 4 & 5 \\
\hline 5 & $\begin{array}{l}\text { If I do not get promoted } \\
\text { soon, I will look for a } \\
\text { job elsewhere. }\end{array}$ & 1 & 2 & 3 & 4 & 5 \\
\hline
\end{tabular}

\section{Section C - Employee Relations}

The following statement is your opinion regarding employee relations. Please circle an appropriate answer to indicate to what degree you agree or disagree for each statement.

\begin{tabular}{|c|l|c|c|c|c|c|}
\hline No. & Employee Relations & $\begin{array}{l}\text { Strongly } \\
\text { Disagree }\end{array}$ & Disagree & Neutral & Agree & $\begin{array}{c}\text { Strongly } \\
\text { Agree }\end{array}$ \\
\hline 1 & $\begin{array}{l}\text { I have good working } \\
\text { relationships with my } \\
\text { colleagues. }\end{array}$ & 1 & 2 & 3 & 4 & 5 \\
\hline 2 & $\begin{array}{l}\text { I have socialized with } \\
\text { my colleagues during } \\
\text { breaks at workplace. }\end{array}$ & 1 & 2 & 3 & 4 & 5 \\
\hline 3 & $\begin{array}{l}\text { My colleagues have } \\
\text { helped me in } \\
\text { performing my tasks. }\end{array}$ & 1 & 2 & 3 & 4 & 5 \\
\hline
\end{tabular}




\section{Section D - Working Environment \& Conditions}

The following statement is your opinion regarding working environment and conditions. Please circle an appropriate answer to indicate to what degree you agree or disagree for each statement.

\begin{tabular}{|c|l|c|c|c|c|c|}
\hline No. & \multicolumn{1}{|c|}{$\begin{array}{c}\text { Working } \\
\text { Environment \& } \\
\text { Conditions }\end{array}$} & $\begin{array}{c}\text { Strongly } \\
\text { Disagree }\end{array}$ & Disagree & Neutral & Agree & $\begin{array}{c}\text { Strongly } \\
\text { Agree }\end{array}$ \\
\hline 1 & $\begin{array}{l}\text { My working conditions } \\
\text { are up to satisfactory } \\
\text { standards. }\end{array}$ & 1 & 2 & 3 & 4 & 5 \\
\hline 2 & $\begin{array}{l}\text { All required resources } \\
\text { are available to me. }\end{array}$ & 1 & 2 & 3 & 4 & 5 \\
\hline 3 & $\begin{array}{l}\text { The working } \\
\text { environment is } \\
\text { conducive. }\end{array}$ & 1 & 2 & 3 & 4 & 5 \\
\hline 4 & $\begin{array}{l}\text { The comfort I am } \\
\text { provided at work is } \\
\text { high. }\end{array}$ & 1 & 2 & 3 & 4 & 5 \\
\hline
\end{tabular}

\section{Section E - Compensation \& Benefit Packages}

The following statement is your opinion regarding compensation and benefit packages. Please circle an appropriate answer to indicate to what degree you agree or disagree for each statement.

\begin{tabular}{|c|l|c|c|c|c|c|}
\hline No. & \multicolumn{1}{|c|}{$\begin{array}{c}\text { Compensation \& } \\
\text { Benefit Packages }\end{array}$} & $\begin{array}{c}\text { Strongly } \\
\text { Disagree }\end{array}$ & Disagree & Neutral & Agree & $\begin{array}{c}\text { Strongly } \\
\text { Agree }\end{array}$ \\
\hline 1 & $\begin{array}{l}\text { I am satisfied with my } \\
\text { total income earned. }\end{array}$ & 1 & 2 & 3 & 4 & 5 \\
\hline 2 & $\begin{array}{l}\text { I am satisfied with the } \\
\text { hourly wage that I } \\
\text { receive. }\end{array}$ & 1 & 2 & 3 & 4 & 5 \\
\hline 3 & $\begin{array}{l}\text { I am satisfied with the } \\
\text { amount of recognition } \\
\text { that I receive. }\end{array}$ & 1 & 2 & 3 & 4 & 5 \\
\hline
\end{tabular}




\section{Section F - Career Advancement Opportunities}

The following statement is your opinion regarding career advancement opportunities. Please circle an appropriate answer to indicate to what degree you agree or disagree for each statement.

\begin{tabular}{|c|c|c|c|c|c|c|}
\hline No. & $\begin{array}{l}\text { Career Advancement } \\
\text { Opportunities }\end{array}$ & $\begin{array}{l}\text { Strongly } \\
\text { Disagree }\end{array}$ & Disagree & Neutral & Agree & $\begin{array}{c}\text { Strongly } \\
\text { Agree }\end{array}$ \\
\hline 1 & $\begin{array}{l}\text { Organization } \\
\text { developmental efforts } \\
\text { have improved my self- } \\
\text { awareness, } \\
\text { competencies, and } \\
\text { employability. }\end{array}$ & 1 & 2 & 3 & 4 & 5 \\
\hline 2 & $\begin{array}{l}\text { I have made sufficient } \\
\text { progress to achieve my } \\
\text { career goals. }\end{array}$ & 1 & 2 & 3 & 4 & 5 \\
\hline 3 & $\begin{array}{l}\text { Organization } \\
\text { management has } \\
\text { provided me with } \\
\text { adequate resources } \\
\text { needed for my } \\
\text { development. }\end{array}$ & 1 & 2 & 3 & 4 & 5 \\
\hline \multirow[t]{2}{*}{4} & \multirow{2}{*}{$\begin{array}{l}\text { Employee development } \\
\text { is perceived in a } \\
\text { positive way. }\end{array}$} & 1 & 2 & 3 & 4 & \multirow[t]{2}{*}{5} \\
\hline & & 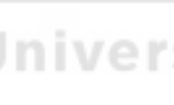 & $i+i$ & ra M & ay & \\
\hline 5 & $\begin{array}{l}\text { Employee development } \\
\text { decisions are made in } \\
\text { an unbiased manner. }\end{array}$ & 1 & 2 & 3 & 4 & 5 \\
\hline
\end{tabular}

END OF QUESTIONNAIRE

THANK YOU 


\section{Appendix 2: Pilot Test Results}

\section{(i) Turnover Intention}

Cesa Frocensing Surnmary

\begin{tabular}{|c|c|c|c|}
\hline & & $\overline{2}$ & $\sqrt{x}$ \\
\hline \multirow[t]{3}{*}{ Cenciod } & verid & 36 & 3000 \\
\hline & Sestadiod $d^{x}$ & a & 3 \\
\hline & tx内 & $2 x$ & 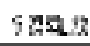 \\
\hline
\end{tabular}

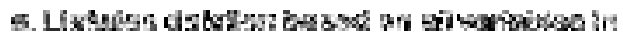

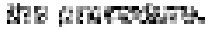

Falegantity hit

\begin{tabular}{|r|r|}
\hline $\begin{array}{c}\text { Clankash's } \\
\text { Alpha }\end{array}$ & Nva Roms \\
\hline ir rg & 5 \\
\hline
\end{tabular}

\begin{tabular}{|c|c|c|c|}
\hline & AHA: & 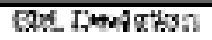 & H \\
\hline 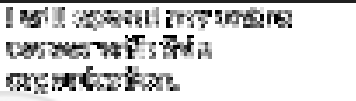 & S.6n & 5.7\% & 30 \\
\hline 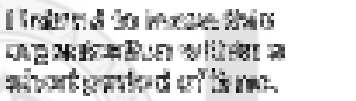 & $x>0$ & 4.335 & 306 \\
\hline 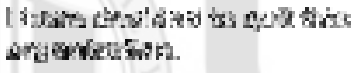 & $2.12 \pi$ & 3.4 138 & 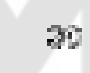 \\
\hline 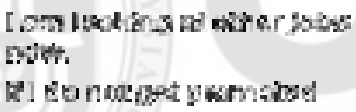 & ass & 4.2 .23 & $\mathrm{Na}$ \\
\hline 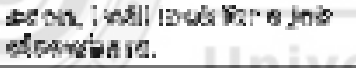 & 3.33 & $9.2 \neq 0$ & 30 \\
\hline
\end{tabular}

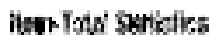

\begin{tabular}{|c|c|c|c|c|}
\hline & 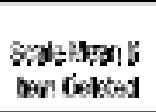 & 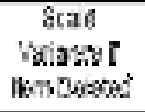 & $\begin{array}{l}\text { Gimitis: } \\
\text { ha-isid } \\
\text { comsigda }\end{array}$ & 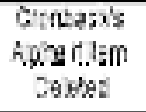 \\
\hline 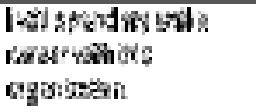 & 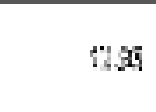 & 蜓. & $x \rightarrow$ & 86 \\
\hline 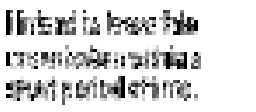 & $12 \%$ & 1is & a & IAd \\
\hline 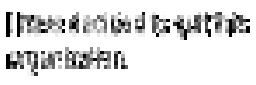 & 12.40 & 10.120 & $\mathbf{M B}$ & Th \\
\hline 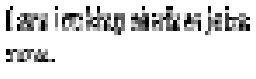 & a.x & 8.525 & $\mathrm{Ks}$ & E.6. \\
\hline 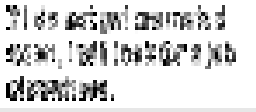 & 528 & $32 x x^{2}$ & Nit & 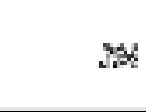 \\
\hline
\end{tabular}

8ospostabies

\begin{tabular}{|c|c|c|c|}
\hline 4:3n & Leisfot & Su Desixia & Fastos \\
\hline Jets & Trent & 3.191 & 5 \\
\hline
\end{tabular}


(ii) Employee Relations

\begin{tabular}{|c|c|c|c|}
\hline & & $\mathrm{N}$ & 86 \\
\hline \multirow[t]{3}{*}{ Coses } & Vsalid & 35 & 100.0 \\
\hline & Evilontants & 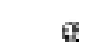 & $s$ \\
\hline & Tote! & Wi & tiald \\
\hline
\end{tabular}

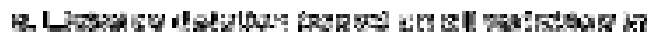
ates provetera

Reliatsifity statieties

\begin{tabular}{|c|c|}
\hline $\begin{array}{c}\text { Crondach's } \\
\text { Apha }\end{array}$ & $\mathrm{N}$ of $\mathrm{Brams}$ \\
\hline .274 & 3 \\
\hline
\end{tabular}

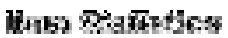

\begin{tabular}{|c|c|c|c|}
\hline & 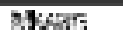 & 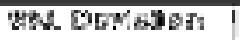 & $\mathrm{E}$ \\
\hline 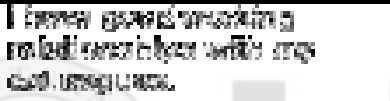 & 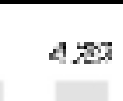 & 744 & $y \approx$ \\
\hline 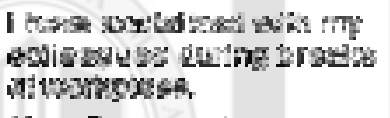 & 초네유 & sact & $3 x$ \\
\hline 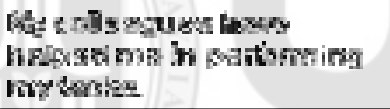 & 5.93 & .722 & 92 \\
\hline
\end{tabular}

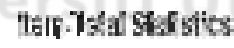

\begin{tabular}{|c|c|c|c|c|}
\hline & 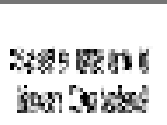 & 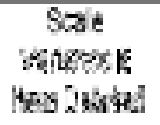 & 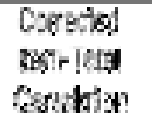 & 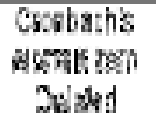 \\
\hline 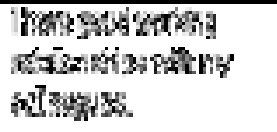 & 283 & arg & 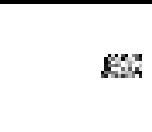 & 20 \\
\hline 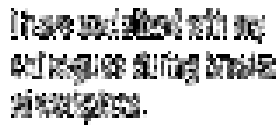 & MO & :54 & , 沙 & S \\
\hline 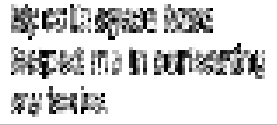 & גם & 280 & $E: H$ & A \\
\hline
\end{tabular}

\section{Wald}

\begin{tabular}{|c|c|c|c|}
\hline (5) & Wyition: & 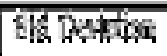 & 商听k \\
\hline 17\% & 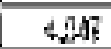 & 3012 & g \\
\hline
\end{tabular}


(iii) Working Environment \& Conditions

\begin{tabular}{|c|c|c|c|}
\hline & & $\mathrm{N}$ & $F_{\%}$ \\
\hline \multirow[t]{2}{*}{ Cass5 } & $\begin{array}{l}\text { Walid } \\
\text { Efelista:as }\end{array}$ & $\begin{array}{r}30 \\
\mathbb{E}\end{array}$ & $\begin{array}{r}100.0 \\
\text { 미 }\end{array}$ \\
\hline & Tutal & 35 & $10 x$. \\
\hline
\end{tabular}

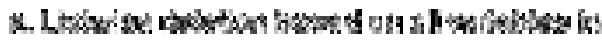
$20 \%$ sostalis.

ReEabaly: Statistics

\begin{tabular}{|c|c|}
\hline $\begin{array}{c}\text { Cicnáan's } \\
\text { arytha }\end{array}$ & Hat'tercen \\
\hline$A^{2} \times 6$ & 4 \\
\hline
\end{tabular}

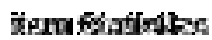

\begin{tabular}{|c|c|c|c|}
\hline & Etan & silu. Bys sther. & $\mathbb{N}$ \\
\hline 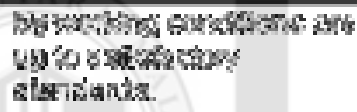 & $25 ?$ & $\$ 4$ & 32 \\
\hline 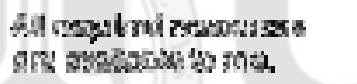 & 2430 & sकी & 3 \\
\hline 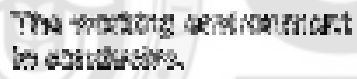 & $3 x$ & 개령요 & $\pi$ \\
\hline 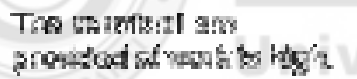 & 2.79 & 개새래 & 2 \\
\hline
\end{tabular}

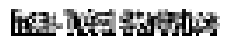

\begin{tabular}{|c|c|c|c|c|}
\hline & 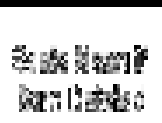 & 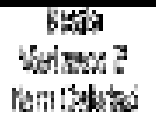 & 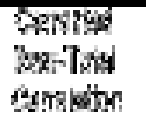 & 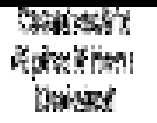 \\
\hline 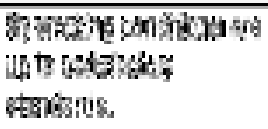 & 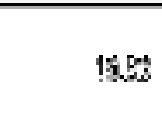 & 经 & BD & $3 \pi$ \\
\hline 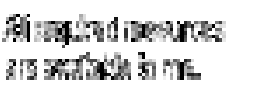 & 1:ist & thess & .74 & 28 \\
\hline 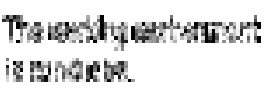 & 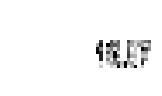 & वैद & S: & its \\
\hline 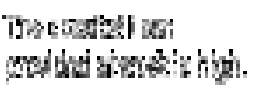 & 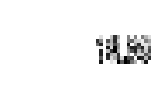 & 연? & 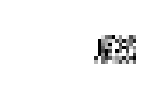 & 435 \\
\hline
\end{tabular}

fedestroftex.

\begin{tabular}{|c|c|c|c|}
\hline Pas & 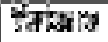 & 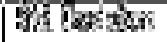 & 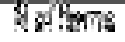 \\
\hline 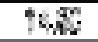 & 3. 36 & 682 & $\frac{1}{4}$ \\
\hline
\end{tabular}


(iv) Compensation \& Benefit Packages

Case Processing bartukary

\begin{tabular}{|c|c|c|c|}
\hline & & BA & $\%$ \\
\hline \multirow[t]{3}{*}{ G4⿻上丨 } & satd & $2 \hat{x}$ & 1 ถิกี้ \\
\hline & intriustos: & $\alpha$ & $\$$ \\
\hline & Tरोड़ा & sh & १द⿱乛龰स \\
\hline
\end{tabular}

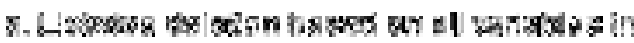
Kง

Feliability Statisfics

\begin{tabular}{|r|r|}
\hline $\begin{array}{c}\text { Cronbach's } \\
\text { Alpha }\end{array}$ & N if Heqms \\
\hline Sfg? & 3 \\
\hline
\end{tabular}

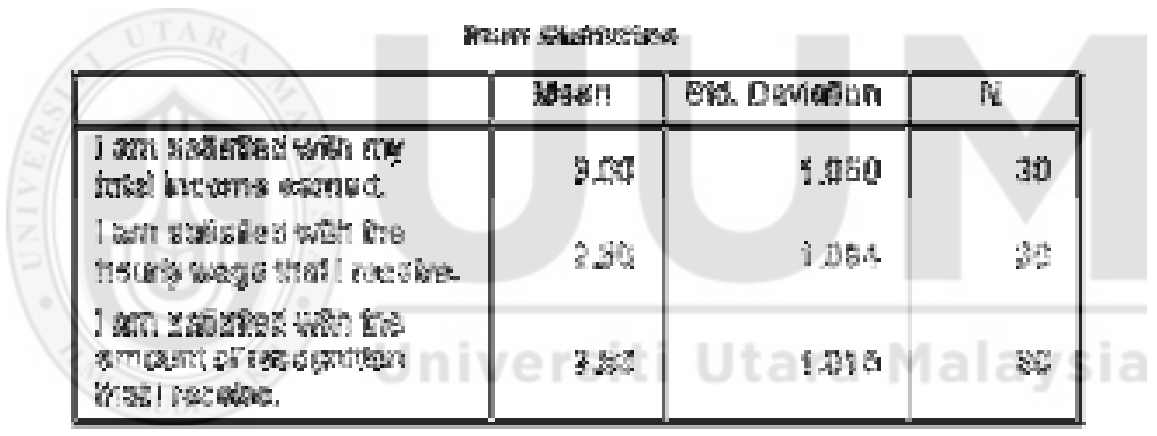

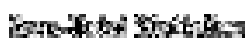

\begin{tabular}{|c|c|c|c|c|}
\hline & 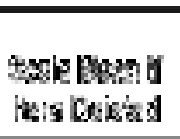 & 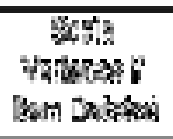 & 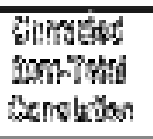 & 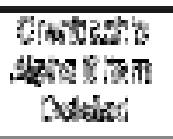 \\
\hline 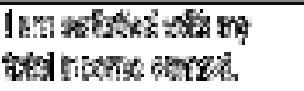 & xa & 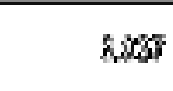 & . & 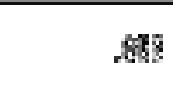 \\
\hline 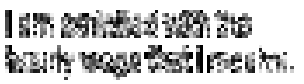 & मू: & $\sin$ & $38 \%$ & ats \\
\hline 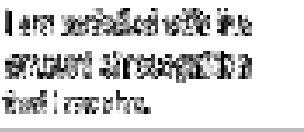 & 5 声得 & S485 & 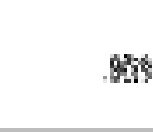 & $\Leftrightarrow 78$ \\
\hline
\end{tabular}

3tals siveax

\begin{tabular}{|c|c|c|c|}
\hline 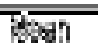 & 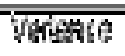 & 可 & 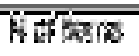 \\
\hline 8.83 & EAd? & $20 \%$ & 3 \\
\hline
\end{tabular}




\section{(v) Career Advancement Opportunities}

Sacprocesing sowetiats

\begin{tabular}{|c|c|c|c|}
\hline & & $\bar{N}$ & 8 \\
\hline \multirow[t]{3}{*}{ cetes } & vas & 30 & 7608 \\
\hline & Batetat" & 5 & .5 \\
\hline & Tos & $2 x$ & extaty \\
\hline
\end{tabular}

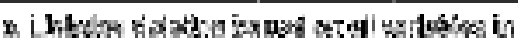
the Rateshins

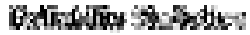

\begin{tabular}{|c|c|}
\hline 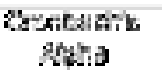 & Mestoutia \\
\hline $25 x$ & $\bar{x}$ \\
\hline
\end{tabular}

\begin{tabular}{|c|c|c|c|}
\hline & Bugn & 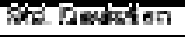 & $\mathrm{k}$ \\
\hline 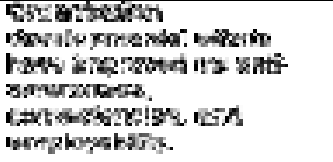 & 4.63 & 1.160 & s6 \\
\hline 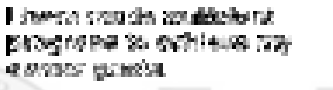 & 2.75 & $28 \%$ & sto \\
\hline 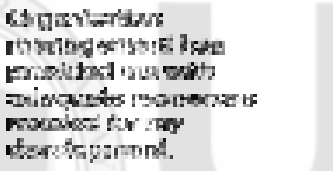 & S. & 2.688 & s\$2 \\
\hline 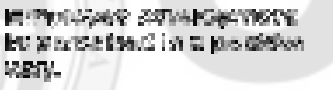 & .3 .53 & 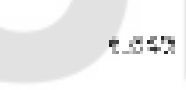 & se \\
\hline 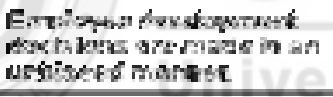 & 8.80 & ข.ร & 20 \\
\hline
\end{tabular}

เมตุ-1

\begin{tabular}{|c|c|c|c|c|}
\hline & 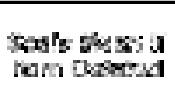 & 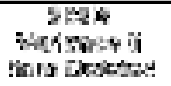 & 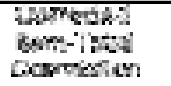 & 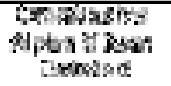 \\
\hline 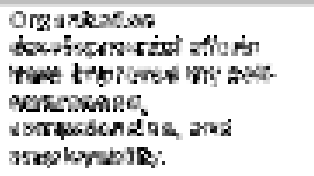 & $94.5 \%$ & 42.062 & $P W=$ & .952 \\
\hline 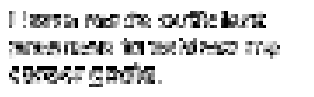 & 13.55 & 10.8\% & RED & as? \\
\hline 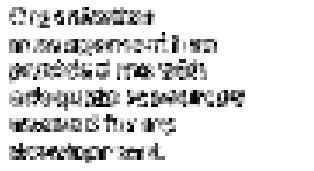 & 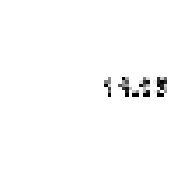 & 1G.4S & $\sec$ & $x=$ \\
\hline 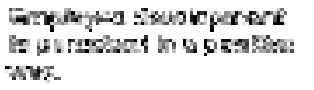 & 18.12 & 2E.75. & FE: & sna \\
\hline 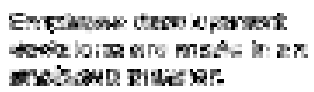 & 17.25 & It 1 , & Ft2s &. $\cos$ \\
\hline
\end{tabular}

Sozle Stotsice

\begin{tabular}{|c|c|c|c|}
\hline thesn & Valanes & ake Denxan & Wofticrese \\
\hline $27 \Omega 3$ & 37.564 & 4.239 & EE \\
\hline
\end{tabular}




\section{Appendix 3: Descriptive Analysis Results for Demographic Profile}

\begin{tabular}{|c|c|c|c|c|c|}
\hline \multicolumn{6}{|c|}{300} \\
\hline & & Exas:umes & Presigant & lato Parterm & 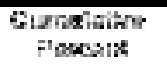 \\
\hline \multirow[t]{6}{*}{$\overline{k .52}$} & 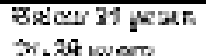 & 2 & 3.7 & 7.7 & 5.7 \\
\hline & 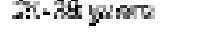 & st & 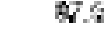 & 60 & $\$ .2$ \\
\hline & स'.5x:54: & $\$ 9$ & 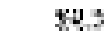 & 20.2 & $2 x$ \\
\hline & 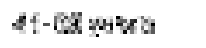 & 3 & St. & 5.5 & 253 \\
\hline & $6 t \cdot 62,5158$ & 2 & E & $a$ & $4: \mathbb{R}: .8$ \\
\hline & resol & 195 & 400 & 403 & \\
\hline
\end{tabular}

\begin{tabular}{|c|c|c|c|c|c|}
\hline \multicolumn{6}{|c|}{ Sansises } \\
\hline & & Frequaxisy & Plsperd & Fede P wask & $\begin{array}{l}\text { Fonizect } \\
\text { funsy: }\end{array}$ \\
\hline Pint: & $\begin{array}{l}\text { Fow: } \\
\text { Foncily } \\
\text { Tokd }\end{array}$ & $\begin{array}{c}3: \\
9 x \\
22\end{array}$ & 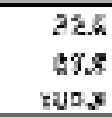 & 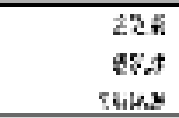 & $\begin{array}{r}25 . h \\
10 \text {. }\end{array}$ \\
\hline
\end{tabular}

\begin{tabular}{|c|c|c|c|c|c|}
\hline \multicolumn{6}{|c|}{ 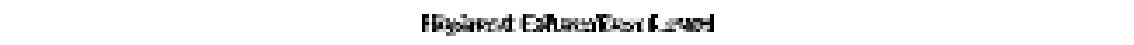 } \\
\hline & & Pascosisy & PBowar & 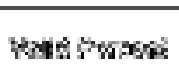 & 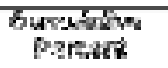 \\
\hline 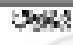 & 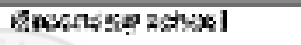 & 5 & 4.4 & $x \not$ & 42 \\
\hline & 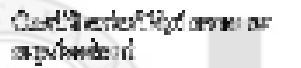 & 36 & Th: & 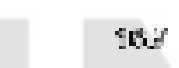 & best \\
\hline & 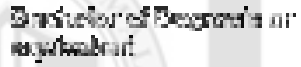 & ER & $\operatorname{ses}$ & $\sin 2$ & osis \\
\hline & 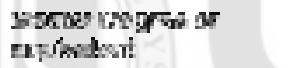 & 8 & $\Delta \lambda$ & 43 & $30 x$ \\
\hline & 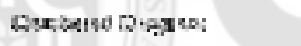 & $r$ & & $\Rightarrow$ & 150.0 \\
\hline & Tesis: & 918 & Vk2: & sctes: & \\
\hline
\end{tabular}

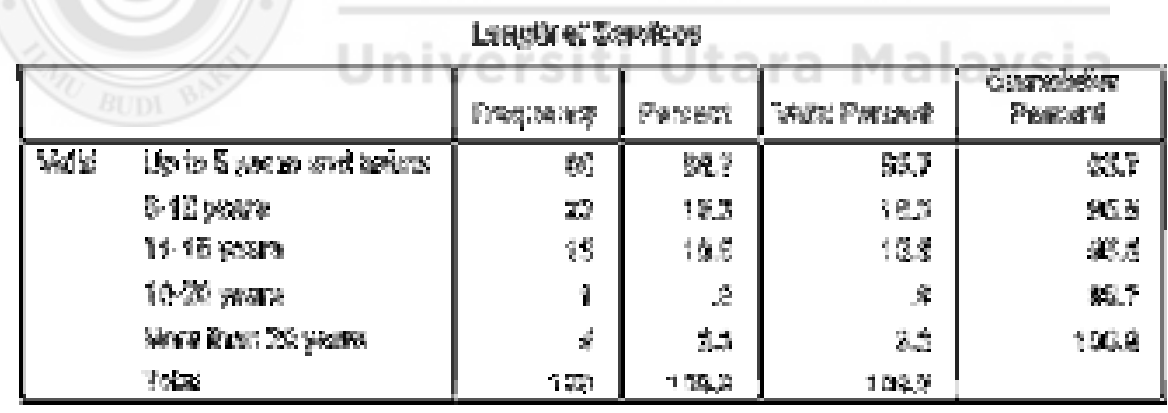

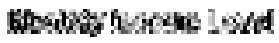

\begin{tabular}{|c|c|c|c|c|c|}
\hline & & 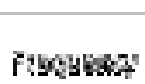 & Parate & 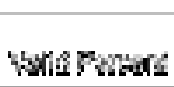 & $\begin{array}{l}\text { Sarentses } \\
\text { Zorst:x }\end{array}$ \\
\hline \multirow[t]{6}{*}{ 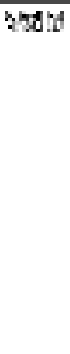 } & 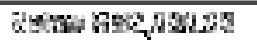 & $x$ & 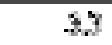 & 38 & 32 \\
\hline & 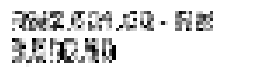 & th & 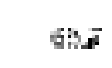 & 80.2 & Tuib \\
\hline & 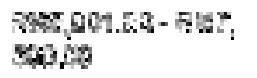 & 83 & is: & 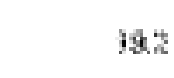 & xy. \\
\hline & 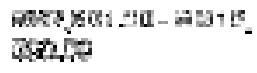 & $1 E$ & PLs & 25 & FISA \\
\hline & 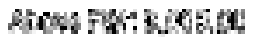 & $i$ & 28 & 26 & Nos \\
\hline & $\int 2 \mathrm{x}$ & 130 & 2)ิt: & $1 \times 2$ & \\
\hline
\end{tabular}




\section{(i) Turnover Intention}

Baseribsthe Statistics

\begin{tabular}{|c|c|c|}
\hline & $\sqrt{7}$ & Parth \\
\hline 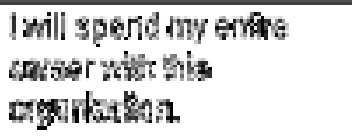 & 128 & 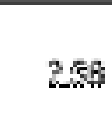 \\
\hline 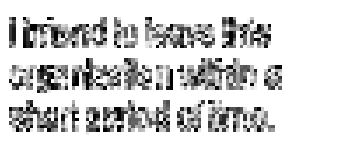 & ร' 251 & 358 \\
\hline 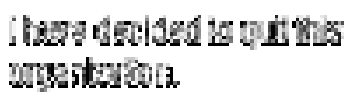 & 㖰 & 2.70 \\
\hline 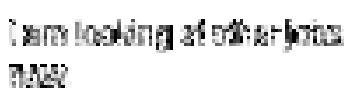 & 125 & $28:$ \\
\hline 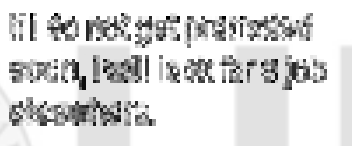 & 13? & 312 \\
\hline 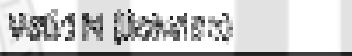 & $153 i$ & \\
\hline
\end{tabular}

(ii) Employee Relations

Descriptive Statistic

\begin{tabular}{|c|c|c|}
\hline & $\bar{N}$ & Mean \\
\hline 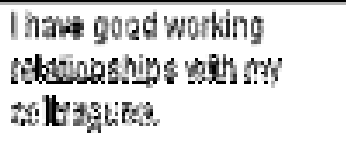 & 130 & 401 \\
\hline 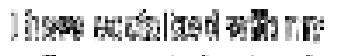 & & \\
\hline 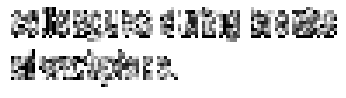 & 135 & $3 E !$ \\
\hline 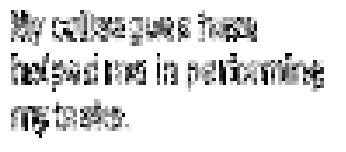 & $98 \check{8}$ & 4 4. \\
\hline 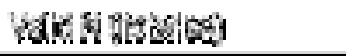 & 923 & \\
\hline
\end{tabular}


(iii) Working Environment \& Conditions

Descriptice Statisács

\begin{tabular}{|c|c|c|}
\hline & $\bar{N}$ & Slea \\
\hline 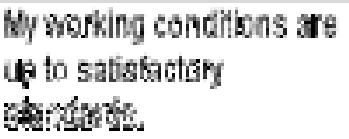 & 129 & 232 \\
\hline 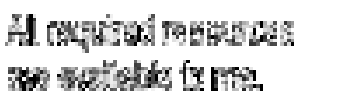 & $12 \pi$ & 3.73 \\
\hline 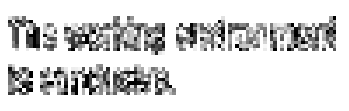 & 13 & 2.래 \\
\hline 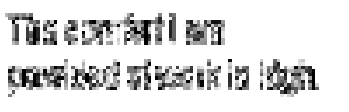 & $12]$ & 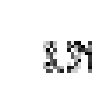 \\
\hline 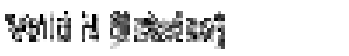 & then & \\
\hline
\end{tabular}

(iv) Compensation \& Benefit Packages

Descriplive Siatistics

\begin{tabular}{|c|c|c|}
\hline & fit & Slean \\
\hline 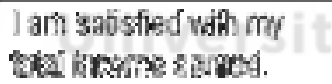 & iss & 2.29 \\
\hline 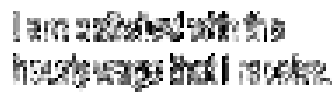 & 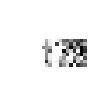 & 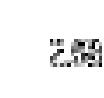 \\
\hline 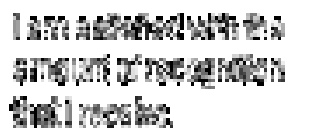 & 137 & 278 \\
\hline 4 & औ"खो & \\
\hline
\end{tabular}


(v) Career Advancement Opportunities

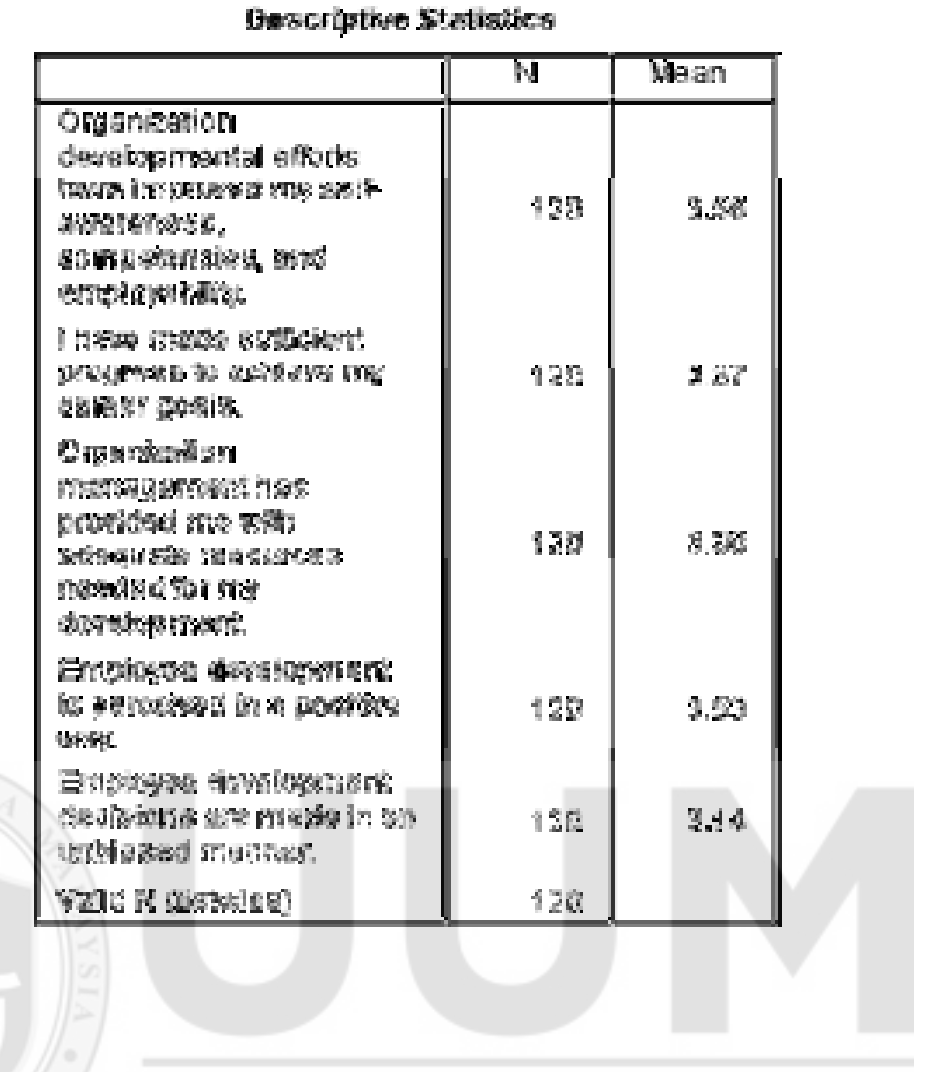

Appendix 5: Pearson Correlation Analysis Results

\section{Correlations}

\begin{tabular}{|c|c|c|c|c|c|c|}
\hline \multicolumn{7}{|c|}{ chmenasm: } \\
\hline & & $\begin{array}{l}\text { Tievesper } \\
\text { ineataph }\end{array}$ & 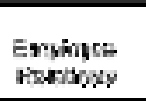 & 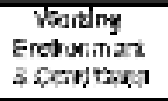 & 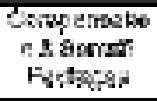 & 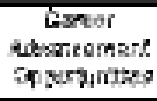 \\
\hline \multirow[t]{3}{*}{ 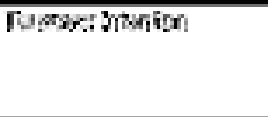 } & Fermon Gomstokn & 7 & $\sqrt{842}$ & $-350^{2}$ & $\sqrt{3} 3^{\circ}$ & . \\
\hline & 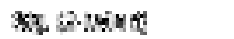 & & $.6 \boldsymbol{x}$ & פด & D9s & .01 \\
\hline & $\pi$ & $\mathbf{1} 84$ & $1 x$ & 179 & 194 & $35 x$ \\
\hline \multirow[t]{3}{*}{ 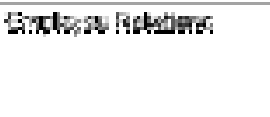 } & Mrask Gmatidn: & -352 & 하 & 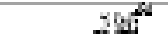 & 191 & i3i \\
\hline & 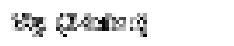 & ND & & 641 & B.? & ine \\
\hline & $r$ & $5 \$ 3$ & dy. & 128 & 120 & 298 \\
\hline \multirow{3}{*}{ 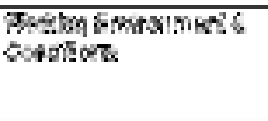 } & 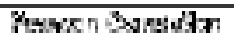 & $+4 E \gamma^{n-1}$ & $2 x x^{n}$ & $?$ & $x_{n}^{n}$ & $\sin 2$ \\
\hline & tor pbones & Sict & not & & an? & $s \pm n$ \\
\hline & $\pi$ & 130 & $y 2$ & 经 & 122 & \pm 2 \\
\hline \multirow{3}{*}{ 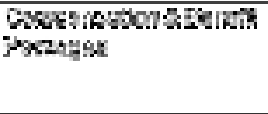 } & Parestionedar & $-2 t^{\prime}$ & $\Delta M$ & $3 x^{2}$ & 1 & $ت \pi^{n}$ \\
\hline & Det 4 -sing of & cos & .363 & D1 & & xhe \\
\hline & R & 293 & $2 \mathrm{C}$ & 190 & 125 & 392 \\
\hline \multirow{3}{*}{ 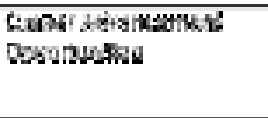 } & Fontencondiath & $.8 t^{2}$ & Iot & $k 6_{x}^{\text {?t }}$ & 32 & 1 \\
\hline & $x g$ p-otsin & idis & प्रs: & $\mathbf{1 E} 0$ & mase & \\
\hline & b: & 428 & 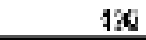 & 193 & $12 k$ & $\widehat{1} \leqslant 2$ \\
\hline
\end{tabular}

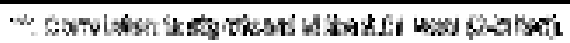




\section{Appendix 6: Multiple Regression Analysis Results}

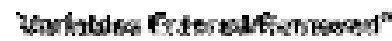

\begin{tabular}{|c|c|c|c|}
\hline iszedz| & $\begin{array}{l}\text { Parboser } \\
\text { Erthod }\end{array}$ & 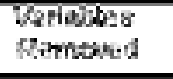 & $M \in D: C \mathrm{~B}$ \\
\hline t & 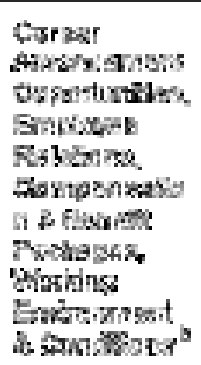 & . & Exider \\
\hline
\end{tabular}

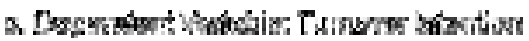

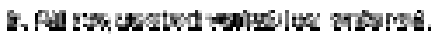

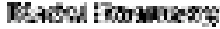

\begin{tabular}{|c|c|c|c|c|}
\hline Uastal & 5 & A Equar & 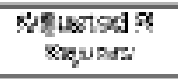 & 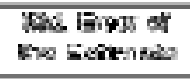 \\
\hline$\frac{9}{1}$ & 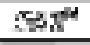 & $3 t 7$ & 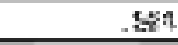 & 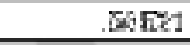 \\
\hline
\end{tabular}

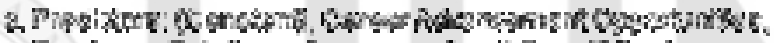

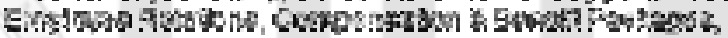

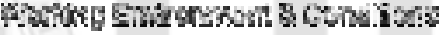

\section{thests}

\begin{tabular}{|c|c|c|c|c|c|c|}
\hline Mosts & & $\begin{array}{l}\text { gictra at } \\
\text { gopuare? }\end{array}$ & tt & Stest soutry & $f$ & bly. \\
\hline \multirow[t]{3}{*}{1} & Fxges: & 18028 & $=4$ & 4. 4. & 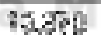 & $\operatorname{Sh}^{3} \mathrm{v}^{3}$ \\
\hline & 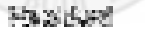 & 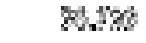 & its & 245 & & \\
\hline & Tyei & 351 & $48 E$ & & & \\
\hline
\end{tabular}

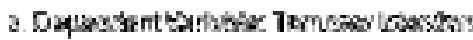

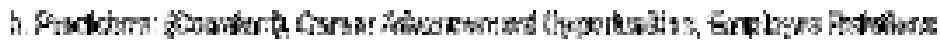

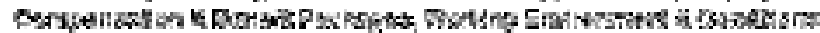

\begin{tabular}{|c|c|c|c|c|c|c|}
\hline \multirow[b]{2}{*}{$\operatorname{sed}$} & & \multicolumn{2}{|c|}{ 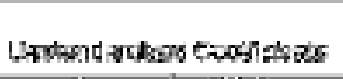 } & \multirow{2}{*}{ 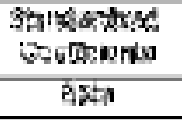 } & \multirow[b]{2}{*}{$t$} & \multirow[b]{2}{*}{ शู. } \\
\hline & & 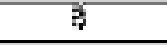 & SWons Ens & & & \\
\hline \multirow[t]{5}{*}{1} & 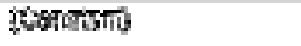 & $4.5 \%$ & est & & 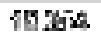 & OAS? \\
\hline & 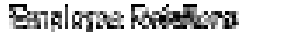 & , 2007 & fons & ates & 7.53 & $5 \%$ \\
\hline & 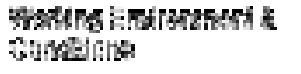 & $-x \in$ & ass: & $-2 \pi x$ & $-2 \pm x$ & est \\
\hline & 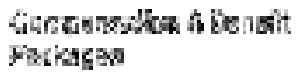 & 4 201 & $\phi_{81}$ & "הist' & $\operatorname{xin} 3$ & 85 \\
\hline & 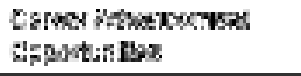 & vint & 168 & 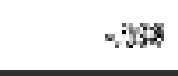 & 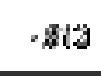 & $2 \phi t^{\circ}$ \\
\hline
\end{tabular}

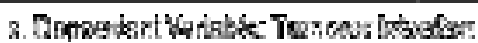

